\title{
Burn severity metrics in fire-prone pine ecosystems along a climatic gradient using Landsat imagery
}

\author{
Víctor Fernández-García ${ }^{\mathrm{a},}$, Mónica Santamarta ${ }^{\mathrm{a}}$, Alfonso Fernández-Manso ${ }^{\mathrm{b}}$, Carmen Quintano ${ }^{\mathrm{c}}$, Elena Marcos $^{\mathrm{a}}$, \\ Leonor Calvo ${ }^{\mathrm{a}}$ \\ ${ }^{a}$ Area of Ecology, Faculty of Biological and Environmental Sciences, University of León, 24071 León, Spain \\ ${ }^{\mathrm{b}}$ Agrarian Science and Engineering Department, University of León, Av. Astorga s/n, 24400 Ponferrada, Spain \\ ${ }^{c}$ Electronic Technology Department, Sustainable Forest Management Research Institute, University of Valladolid, Spanish National Institute for Agriculture and Food Research and Technology \\ (INIA), C/Francisco Mendizábal s/n, 47014 Valladolid, Spain
}

\section{A R T I C L E I N F O}

Keywords:

Composite Burn Index

dNBR-EVI

Fire severity

Mediterranean-Transition-Oceanic climatic

conditions

Pine forest

Spectral index

\begin{abstract}
A B S T R A C T
Multispectral imagery is a widely used source of information to address post-fire ecosystem management. The aim of this study is to evaluate the ability of remotely sensed indices derived from Landsat 8 OLI/TIRS to assess initial burn severity (overall, on vegetation and on soil) in fire-prone pine forests along the Mediterranean-Transition-Oceanic climatic gradient in the Mediterranean Basin. We selected four large wildfires which affected pine forests in a climatic gradient within the Iberian Peninsula. In each wildfire we established CBI plots to obtain field values of three burn severity metrics: site, vegetation and soil burn severity. The ability of 13 spectral indices to match these three field burn severity metrics was compared and their transferability along the climatic gradient assessed using linear regression models. Specifically, we analysed the performance of 12 indices previously used for burn severity assessments ( 8 reflective, 2 thermal, 2 mixed) and a new reflective index (dNBR-EVI). The results showed that Landsat spectral indices have a greater ability to determine site and vegetation burn severity than soil burn severity. We found large differences in indices performances among the three different climatic regions, since most indices performed better in the Mediterranean and Transition regions than in the Oceanic one. In general, the dNBR-EVI showed the best fit to site, vegetation and soil burn severity in the three regions, demonstrating broad transferability along the entire climatic gradient.
\end{abstract}

\section{Introduction}

Wildfire is a natural process identified as a serious environmental and socio-economic problem in some regions of the world (Nunes et al., 2016). Indeed, in the European countries of the Mediterranean Basin, wildfires represent the most important abiotic disturbance (Lindner et al., 2008), and they have increased significantly in number since 1980 (San-Miguel-Ayanz et al., 2016). Predictions of future fire regimes forecast an increase in the severity of wildfires in the Mediterranean Basin, under a warmer and drier climate (Lindner et al., 2008; Moreira et al., 2011; Doblas-Miranda et al., 2017). The consequences of fire are highly dependent on burn severity (Pausas et al., 2008; Keeley, 2009; González-de-Vega et al., 2016). This parameter is defined as the change in the burnt area with respect to the pre-fire situation (Key and Benson, 2006; De Santis et al., 2010; Soverel et al., 2011;
Meng et al., 2017), and operationally denoted as the aboveground and belowground organic matter consumed by fire (Keeley, 2009).

In Southern Europe, for instance the Iberian Peninsula, forests most affected by wildfires are the fire-prone pine ecosystems (Dimitrakopoulos et al., 2011). In these forests, burn severity plays a key role in the recovery capacity of both vegetation and soil (Calvo et al., 2008; Lindner et al., 2008; Pausas et al., 2008; González-de-Vega et al., 2016). In general, Pinus species in the Iberian Peninsula's forests are obligated seeders whose post-fire regeneration relies on seeds stored in serotinous cones within the canopy level (Calvo et al., 2008, 2016). However, this natural regeneration could fail due to severe wildfires, as regeneration from aerial seed banks could be hindered (Calvo et al., 2008; Catry et al., 2013). Depending on burn severity, fire not only affects the regeneration of dominant tree species but also the understory community. Burn severity increases mortality and interacts with regeneration strategies, affecting species with different bio-

\footnotetext{
* Corresponding author.

Email addresses: vferg@unileon.es (V. Fernández-García); msantl04@estudiantes.unileon.es (M. Santamarta); alfonso.manso@unileon.es (A. Fernández-Manso); menchu@tele.uva.es (C. Quintano); elena.marcos@unileon.es (E. Marcos); leonor.calvo@unileon.es (L. Calvo)
} 
logical traits in different ways and jeopardizing the recovery of some of them (Céspedes et al., 2014; Pausas and Keeley, 2014; González-de-Vega et al., 2016).

In addition, burn severity has several impacts on the soils in fire-prone ecosystems. Whereas low severity has almost negligible or non-negative impacts on soils (Marcos et al., 2009; Alcañiz et al., 2016), high burn severity may cause significant loss of organic matter (Vega et al., 2013), development of hydrophobicity with depth (Rodríguez-Alleres et al., 2012), and deterioration of soil structure (Varela et al., 2015), thus contributing to soil losses (Certini, 2005; Lindner et al., 2008). Soil erosion is probably the most serious ecological threat during the first year after fire in high burn severity areas (Fernández and Vega, 2016), and damage can be significant in regions like the Iberian Peninsula, where the risk of potential erosion is very high (Van der Knijff et al., 2000). Consequently, initial assessments of burn severity are necessary to address the potential post-fire management strategies aimed at maintaining the vegetation community and preserving the soil.

There are several ways to assess burn severity in the field, among which the Composite Burn Index (CBI) (Key and Benson, 2006) has been identified as a standard measurement (e.g. Fernández-Manso and Quintano, 2015; Kong et al., 2015; Quintano et al., 2015; Holden et al., 2016; Meddens et al., 2016; Parks et al., 2016; Day et al., 2017). The CBI has been initially proposed for calibration and validation of remote sensing products of burn severity the first months after fire (initial assessment) or the first growing season after fire (extended assessment) in Western United States (Key and Benson, 1999; Key and Benson, 2006), and it has been adapted for use in different regions (Epting et al., 2005; Kasischke et al., 2008). The CBI approach is more complete than many other classification systems based on single indicators of burn severity (Sikkink, 2015), because it employs several visually estimated metrics of four vegetation strata (vegetation burn severity) and soil (soil burn severity), which can be used together (site burn severity) providing an overall idea of the damage caused by fire, or separately, depending on compartments considered key in post-fire management (Key and Benson, 2006; Zhu et al., 2006; Keeley, 2009). Although several limitations of CBI have been noted, such certain subjectivity on its estimation without knowing the pre-fire situation (Lentile et al., 2009), the CBI is a burn severity index of great interest for land managers and scientists (Holden et al., 2016) due to its integrative nature, rapid application and known relation with many other impacts on the ecosystems and post-fire recovery (e.g. Johnstone et al., 2010; Schwilk and Caprio, 2011; Kong et al., 2015; Holden et al., 2016; Day et al., 2017).

In large forest fires the assessment of burn severity by using only field measurements is not functional, the use of remote sensing methods being necessary (De Santis and Chuvieco, 2007; Wu et al., 2015; Meng et al., 2017). In order to tackle this challenge, various remote sensing methods have been used, including those based on spectral mixture analysis (SMA) (Fernández-Manso et al., 2009; Quintano et al., 2017), radiative transfer models (RTM) (Chuvieco et al., 2006; De Santis et al., 2009) or spectral indices (Chu and Guo, 2014; Wu et al., 2015; Fernández-Manso et al., 2016; Zheng et al., 2016). SMA and RTM have some advantages over spectral indices for burn severity mapping. SMA can be applied to any type of reflective remotely sensed image (multispectral/hyperspectral), independently of their spatial resolution or specific bands, and allows analogous products to some field burn severity measurements to be obtained, having an explicit physical meaning (Lentile et al., 2009). RTM is a physically-based method (Meng et al., 2017), which can model burn severity variables regardless of study site characteristics (De Santis et al., 2009). Furthermore, RTM have successfully achieved higher correlations with field burn severity than spectral indices in temperate and Mediterranean ecosystems (De Santis and Chuvieco, 2007; De Santis et al., 2009; De Santis et al., 2010). However, spectral indices are still the most commonly used method (Key and Benson, 2006; Keeley, 2009; Veraverbeke et al., 2012; Chu and Guo, 2014; Fernández-Manso and Quintano, 2015), because they can be highly accurate when matching field measurements of burn severity using a simple calculation process (Miller and Thode, 2007; Parks et al., 2014; Fernández-Manso et al., 2016; Zheng et al., 2016), but most studies analysing spectral indices performance have been carried out in North America (Epting et al., 2005; Miller and Thode, 2007; Harris et al., 2011; Cansler and McKenzie, 2012; Parks et al., 2014; Zheng et al., 2016), further evaluations in other regions being advisable.

Among the many factors that can affect the spectral indices performance, climate is one of great interest due to its influence on several proximate factors, which can modify the land surface reflectance and/ or thermal emissivity. For instance, along different climates, vegetation may have different leaf pigmentation (Xiao and Moody, 2008), leaf area (Myneni et al., 2002; Zhu et al., 2013), and geometry (Box, 1981); and soils have different moisture content (Reichle and Koster, 2004). Despite this influence, few studies have indicated the relevance of climate-related proximate factors in burn severity assessments (Roy et al., 2006; Picotte and Robertson, 2011; Soverel et al., 2011; Parks et al., 2014).

The Landsat 8 satellite allows us to obtain reflective indices, thermal metrics, and mixed indices combining reflective and thermal, so the capacity of these spectral indices to assess burn severity can be compared (Vlassova and Pérez-Cabello, 2016). Most spectral indices can be calculated from a mono-temporal perspective (post-fire situation) or from a bi-temporal perspective (difference between pre-fire and post-fire situations) (Epting et al., 2005; Harris et al., 2011). The main advantage of using mono-temporal indices is the reduction in errors associated with differences in vegetation phenology potentially expected with bi-temporal approaches (Epting et al., 2005), due to imagery acquisition data or because of inter-annual meteorological differences (Veraverbeke et al., 2010). However, the literature usually indicates that bi-temporal indices are more correlated to field burn severity measurements (Key, 2006; Key and Benson, 2006; Miller and Thode, 2007; Zheng et al., 2016).

Spectral indices based on the opposite response of Near Infrared (NIR) and Short Wave Infrared (SWIR) regions, specifically the NBR and its bi-temporal approach called dNBR (Key, 2006), are considered a reference for burn severity mapping (De Santis et al., 2010; Veraverbeke et al., 2012; Parks et al., 2014). Although some authors have found their performance suboptimal (Chuvieco et al., 2006; Roy et al., 2006), other indices based on NBR have been proposed obtaining good results, for instance the RdNBR (Miller and Thode, 2007) and the RBR (Parks et al., 2014), calculated by relativizing the bi-temporal NBR with the pre-fire NBR. Other reflective metrics, such the typical vegetation NDVI (Rouse et al., 1973) and EVI (Gao et al., 2000) indices have been used in burn severity assessments, both mono and bi-temporal approaches obtaining good results (Wu et al., 2015). Additionally, in recent years, thermal infrared data is starting to be used for burn severity assessments (Vlassova et al., 2014; Quintano et al., 2015, 2017), but there are few studies assessing their bi-temporal approach (Zheng et al., 2016). Thermal remotely sensed information can be easily transformed to land surface temperature (LST), which is a function of soil and air temperature, both of which are positively related to burn severity (Marcos et al., 2009; Vlassova and Pérez-Cabello, 2016). Other authors have sought to improve the functioning of the reflective indices incorporating a thermal component, resulting in mixed burn severity indices that could outperform reference indices such as dNBR (Veraverbeke et al., 2011; Zheng et al., 2016).

Therefore, numerous spectral metrics from Landsat data to quantify burn severity can be found, but there is no consensus about the most appropriate alternative (Cansler and McKenzie, 2012), highlighting the 
importance of developing more specific research. Thus, there are few studies comparing the capacity of spectral indices to detect site, vegetation and soil burn severity separately (Hudak et al., 2007), and it may be of great interest for a better understanding of indices performance. Differences in spectral indices retrieval of soil and vegetation burn severity can be expected, due to the different sensitivity of each region of the spectrum to each particular change in soil and in vegetation (Key and Benson, 2006; Chuvieco, 2010; Veraverbeke et al., 2011; Vlassova et al., 2014). Additionally, finding spectral indices with a great ability to map the site, vegetation and soil burn severity is of great value in defining emergency areas, especially in those ecosystems dominated by obligate seeders or with high vulnerability to soil erosion, such the fire-prone pine forests of the Iberian Peninsula (Van der Knijff et al., 2000; Calvo et al., 2008; Fernández and Vega, 2016; González-de-Vega et al., 2016).

The objective of this study is to evaluate the ability of remotely sensed indices derived from Landsat sensors for initial burn severity assessments in fire-prone ecosystems dominated by Pinus species along the Mediterranean-Transition-Oceanic climatic gradient. Specifically, we aim to answer the following questions: (1) Which spectral indices (reflective, thermal or mixed) have the best fit to field measurements of burn severity (CBI) along the Mediterranean-Transition-Oceanic climatic gradient? (2) Do the remotely sensed indices have the same ability in assessing site burn severity (vegetation plus soil) as vegetation burn severity or soil burn severity individually? (3) Is there any spectral index transferable throughout climatic regions with a high ability to indicate burn severity in the ecosystem (site burn severity) and its compartments (vegetation and soil burn severity)?

\section{Methods}

The followed methodology comprises four steps: study sites selection, field measurements of burn severity, remotely sensed data and data analysis (Fig. 1).

\subsection{Study sites}

Four wildfires were selected along the Mediterranean-Transition-Oceanic climatic gradient within the Iberian Peninsula (Mediterranean, Transition1, Transition2 and Oceanic sites) (Table 1). All of them affected closed-canopy forests basically dominated by Pinus pinaster

Ait.,

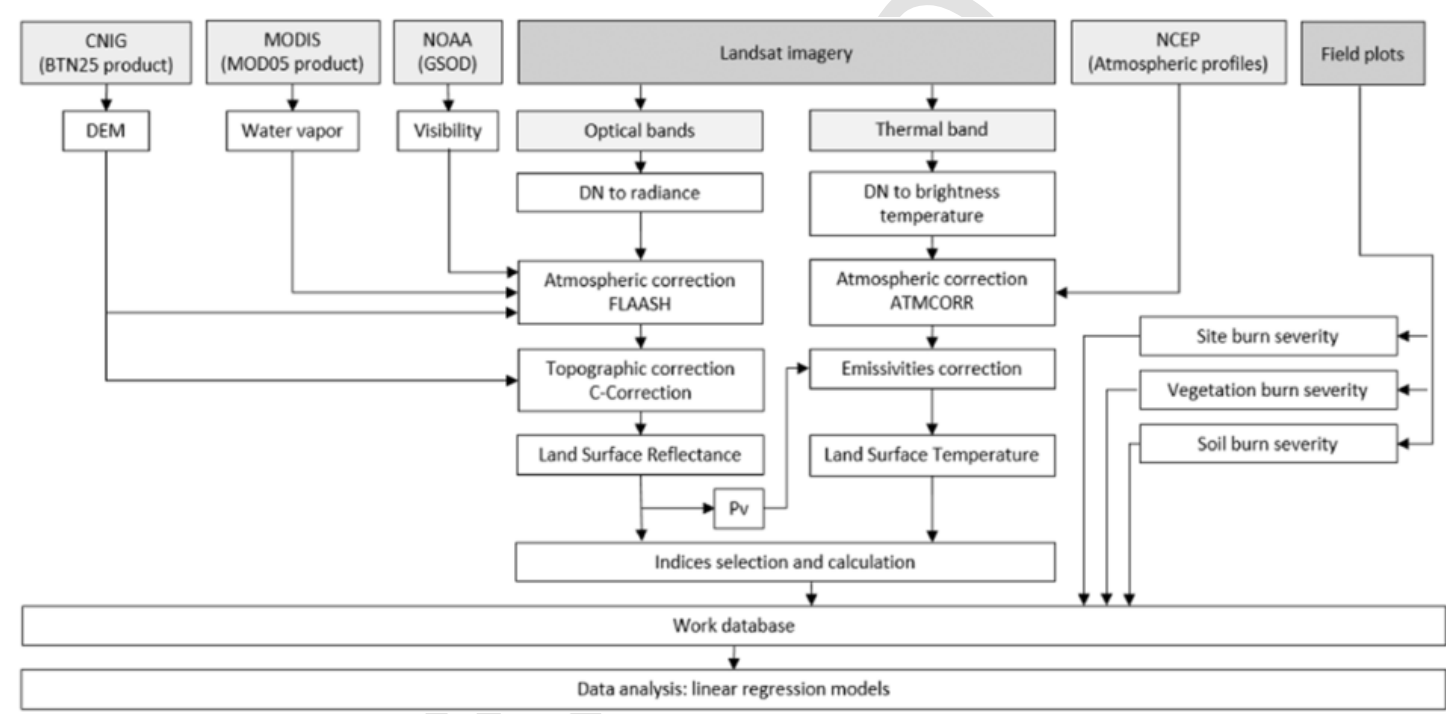

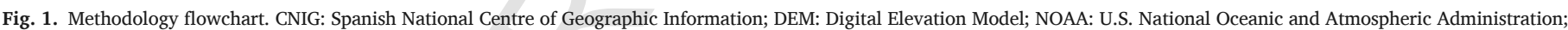
NCEP: U.S. National Centres for Environmental Prediction; Pv: proportion of vegetation cover.

Table 1

Characteristics of study sites.

\begin{tabular}{|c|c|c|c|c|}
\hline & Mediterranean site & Transition 1 site & Transition2 site & Oceanic site \\
\hline Fire alarm date & August 6th, 2015 & August 19th, 2012 & July 13th, 2015 & July 28th, 2015 \\
\hline Wildfire size $\left(\mathrm{km}^{2}\right)$ & 88.90 & 118.91 & 26.00 & 5.79 \\
\hline Elevation (m) & $275-1449$ & 836-1493 & $1032-1531$ & $231-768$ \\
\hline Aspect & $\mathrm{S}, \mathrm{W}, \mathrm{E}$ & $\mathrm{N}, \mathrm{S}, \mathrm{W}, \mathrm{E}$ & $\mathrm{s}$ & $\mathrm{N}, \mathrm{S}, \mathrm{W}, \mathrm{E}$ \\
\hline Mean annual precipitation $(\mathrm{mm})^{\mathrm{a}}$ & 702 & 612 & 703 & 934 \\
\hline Mean July precipitation $(\mathrm{mm})^{\mathrm{a}}$ & 7 & 20 & 30 & 40 \\
\hline Mean annual temperature $\left({ }^{\circ} \mathrm{C}\right)^{\mathrm{a}}$ & 14.3 & 10.7 & 10.0 & 10.8 \\
\hline Mean July temperature $\left({ }^{\circ} \mathrm{C}\right)^{\mathrm{a}}$ & 23.6 & 19.6 & 18.3 & 17.2 \\
\hline Mean summer soil moisture (\%) & 9.3 & 22.5 & 29.2 & 40.6 \\
\hline Köppen classification ${ }^{\mathrm{c}}$ & Csa & $\mathrm{Csb}$ & $\mathrm{Csb}$ & $\mathrm{Cfb}$ \\
\hline Quantity of fires $\left(\mathrm{N} * 10 \mathrm{~km}^{2-1} * 10 \text { years }^{-1}\right)^{\mathrm{d}}$ & 12.2 & 4.7 & 4.9 & 12.8 \\
\hline Average size of fires $\left(\mathrm{km}^{2}\right)^{\mathrm{d}}$ & 0.18 & 0.64 & 0.16 & 0.08 \\
\hline
\end{tabular}

a Precipitation and temperature are 1982 to 2012 averages.

b Soil moisture in the summer of the wildfire occurrence, measured as the percentage of soil water with respect to the amount of water that the soil could retain (Data provided by the Spanish meteorological survey - AEMET).

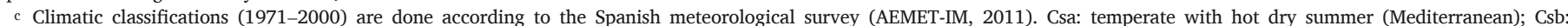
temperate with dry temperate summer (Transition); $\mathrm{Cfb}$ : temperate without a dry season and temperate summer (Oceanic).

d Fire statistics are 1998-2008 averages (MAGRAMA, 2009). 
with a similar fuel structure, fuel model number 7 according to Anderson (1982).

The Mediterranean site is located in Cáceres province, Spain (Fig. 2), where $88.90 \mathrm{~km}^{2}$ burned in summer 2015. The fire regime in this area is characterized by a relatively high number of wildfires (MAGRAMA, 2009) (Table 1). The site combines mountainous terrain with almost no northern exposure with flat areas. Soils are acidic and mainly originated from biotitic-granitic lithologies and slash. The forest is dominated by $P$. pinaster. This region is characterized by typical Mediterranean conditions with 4 months of summer drought.

The Transition 1 site is a mega-wildfire occurred in summer 2012 in the south of León province, Spain (Fig. 2), where there are few fires (MAGRAMA, 2009). This wildfire burned $118.91 \mathrm{~km}^{2}$ of $P$. pinaster stands developed over siliceous lithologies (quartzite, sandstone and slate) in a heterogeneous topography (Table 1).
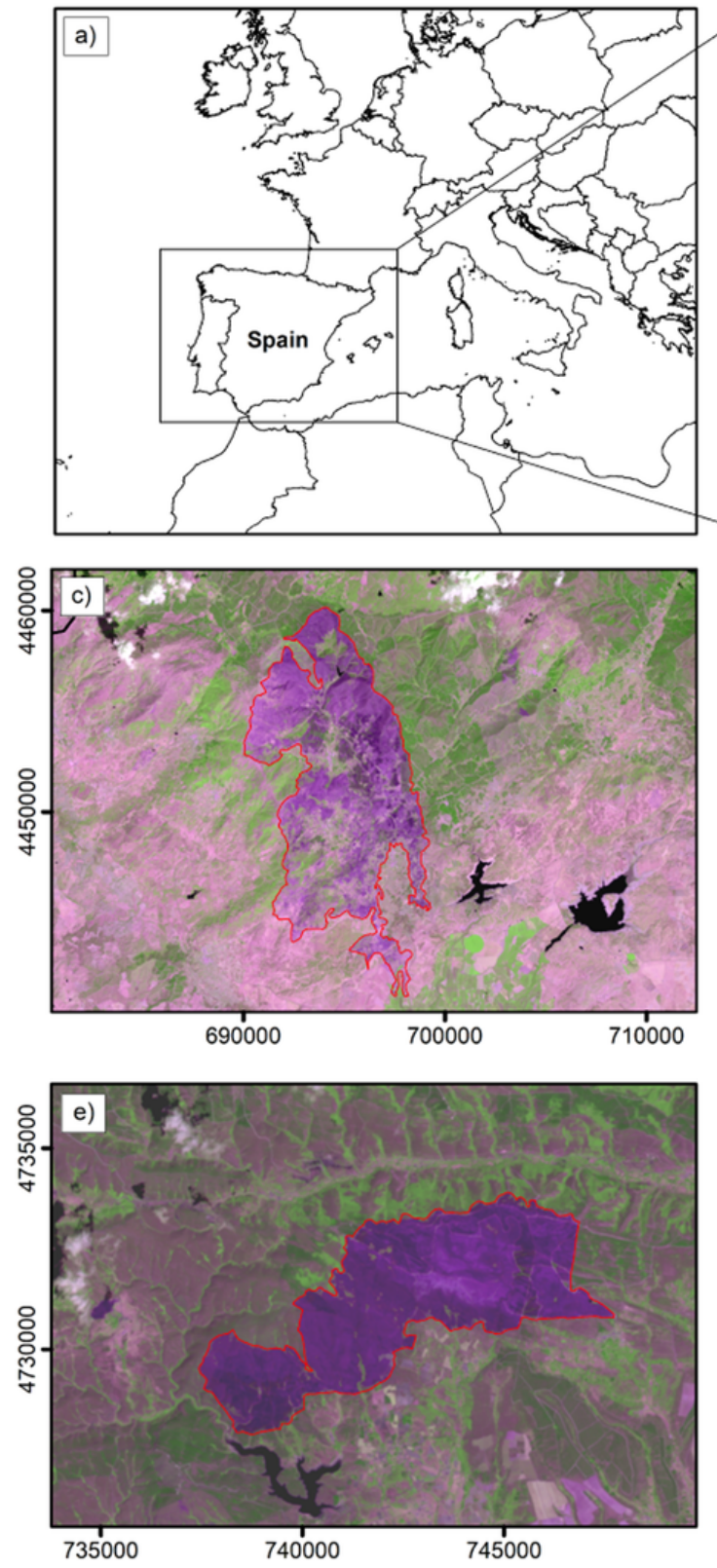

The Transition2 site is located in the north of León province (Fig. 2), where a wildfire affected $26.00 \mathrm{~km}^{2}$. In this area there are few fires (MAGRAMA, 2009) (Table 1). The site is a south-exposed hillside, where soils are acidic, originated from arkosic sands, slash, sandstone and quartzite. The forest is dominated by $P$. pinaster with occasional presence of $P$. nigra Arn. and $P$. sylvestris L. The Transition region is characterized by a summer drought of 2 months, an intermediate period between the Mediterranean climate and Oceanic climates (with no summer drought).

The Oceanic wildfire occurred in Asturias province, Spain (Fig. 2), and burned $5.79 \mathrm{~km}^{2}$. The rugged terrain topography and patchy landscape (García-Llamas et al., 2016) cause wildfires in this region to be smaller (MAGRAMA, 2009). Soils are acidic, originated from slash, sandstone and conglomerate. The dominant tree species is $P$. pinaster with occasional presence of $P$. radiata D. Don. In this region there is no summer drought.
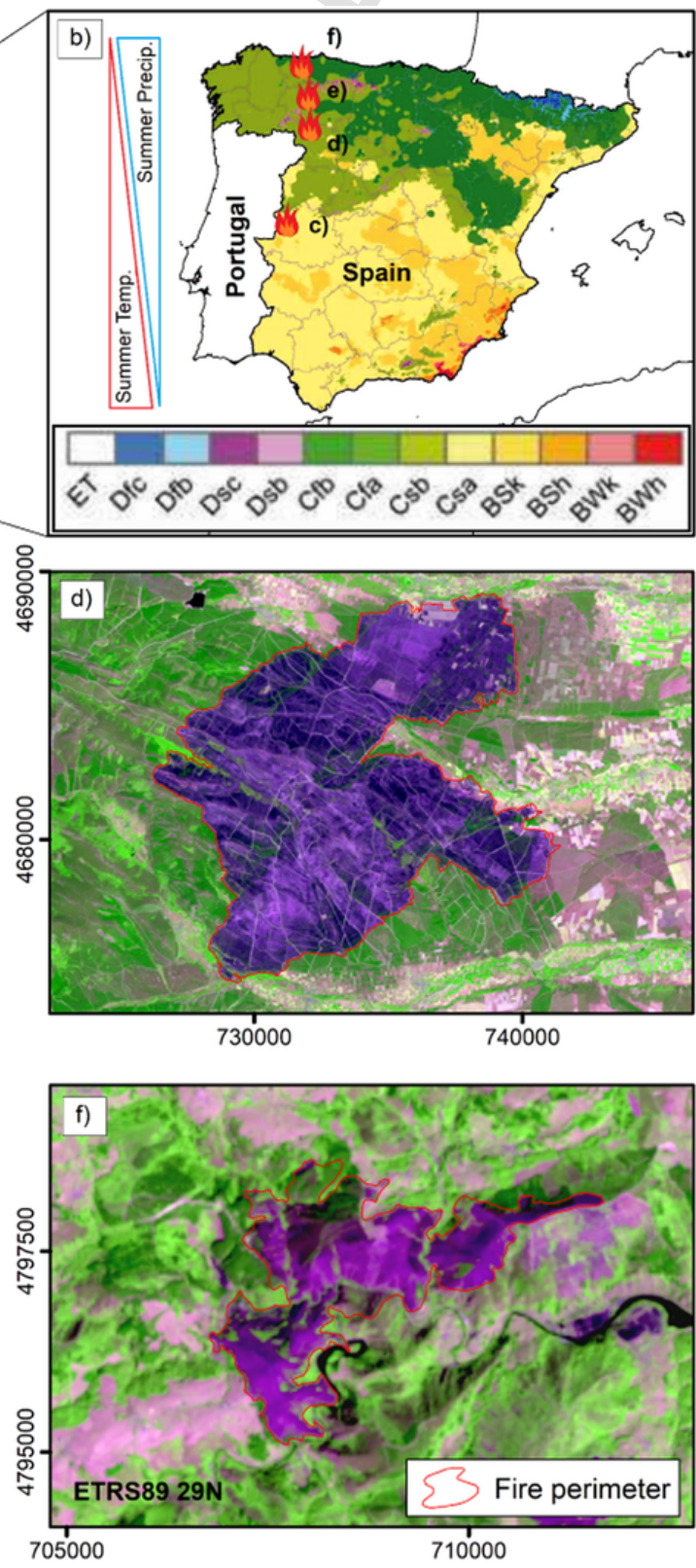

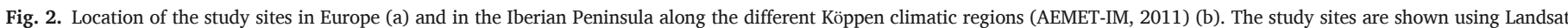

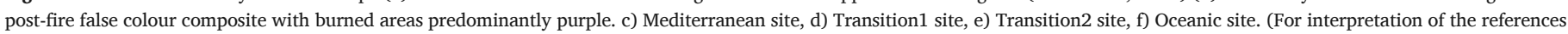
to colour in this figure legend, the reader is referred to the web version of this article.) 


\subsection{Field measurements of burn severity}

Field data to quantify the initial burn severity were collected three months after wildfires in the four study sites. $30 \mathrm{~m}$ diameter field plots were randomly distributed in fairly homogeneous patches of at least $100 \mathrm{~m}$ diameter throughout each wildfire and positions were GPS recorded.

According to the sampling intensity reported in other studies (e.g. De Santis et al., 2010; Wu et al., 2015; Zheng et al., 2016), we distributed a total of 183 plots among the four wildfires: 58 in the Mediterranean site, 54 in the Transition 1 site, 48 in the Transition 2 site, and 23 in the Oceanic site. To ensure that the number of plots was enough in each wildfire we used the following formula (Chuvieco, 2010):

$\mathrm{n}=\mathrm{z}^{2} \mathrm{~s}^{2} /\left(\mathrm{L}^{2}+\mathrm{s}^{2} \mathrm{z}^{2} / \mathrm{N}\right)$

where $\mathrm{n}$ is the minimum sampling size, $\mathrm{z}$ is the $\mathrm{z}$-coefficient for a specific confidence level, $\mathrm{L}$ is the minimum detectable change or assumable error, $\mathrm{s}^{2}$ is the variance of the samples, and $\mathrm{N}$ is the population size. We assumed an error of $0.5 \mathrm{CBI}$ points and a confidence level of $95 \%$.

Our field protocol to quantify burn severity (Table 2) is an adapted version of the original CBI (Key and Benson, 2006). The sampling procedure consists of rating several variables from 0 points (unburned) to 3 points (maximum burn severity) in 5 strata (Table 2), obtaining an average burn severity value per stratum. The site burn severity score is the average value of all evaluated strata, the vegetation burn severity is the average value of all evaluated strata except substrate, and the soil burn severity only considers the substrate stratum (Fig. 3). In our adapted CBI we did not consider factors that have to be measured in extended assessments (\% of living shrubs, colonizers, or change in species composition). In the substrate stratum rating factors we did not use medium and heavy fuel consumption, because they were not significantly present in the study sites.

\subsection{Remotely sensed data}

Remotely sensed information to estimate burn severity was obtained from Landsat imagery (Landsat 8 OLI/TIRS for the Mediterranean, Transition 2 and Oceanic fires, and Landsat 7 ETM + for the Transition1 site). Pre-fire and post-fire scenes were acquired for each fire from the USGS Earth Explorer server (http://earthexplorer.usgs.gov/). We selected imagery without clouds, and as close as possible to the fire date. Scenes in the Mediterranean site were from June 19th, 2015 and September 7th, 2015; in the Transition1 site from September 20th, 2011 and September 6th, 2012; in the Transition2 site from June 19th, 2015 and August 6th, 2015; and in the Oceanic site from June 26th, 2015 and August 29th, 2015.

Landsat imagery provided by the USGS (L1T processing level) is a Digital Numbers (DN) product geometrically rectified and radiometrically corrected (Landsat 8 (L8) Data Users Handbook, 2016; Landsat 7 Science Data Users Handbook, 2017). In this product we can distinguish optical or reflective bands (B1 to B9 in Landsat 8; B1 to B5, B7 and B8 in Landsat 7), and thermal bands (B10 and B11 in Landsat 8; B6L and B6H in Landsat 7), to which we applied different pre-processing treatments.

The reflective bands were spatially subset and pre-processed (Fig. $1)$. DN were transformed to radiance values $\left(\mathrm{L}_{\lambda}\right)$, which were atmospherically corrected using the Fast Line-of-sight Atmospheric Analysis of Spectral Hypercubes (FLAASH) module (Perkins et al., 2012) in ENVI. We used the MODIS water vapor product (MOD05), meteorological data (NOAA) and mean elevation values to set the appropriate atmosphere models, aerosol situations and input parameters. Topographic shadow effects were removed by C-correction algorithm (Teillet et al., 1982), using a digital elevation model (DEM) generated from the BCN25 product of the National Centre of Geographic Information of Spain (CNIG). We used $10 \%$ of the pixels to define the C constant of the algorithm (Quintano et al., 2015). Finally, topographic corrected values were rescaled to land surface reflectance in percentage $(\rho)$. These corrections are convenient due to the relevant effect of atmosphere on some bands and because of the rough terrain in some

Table 2

Modified Composite Burn Index used in this study to obtain the field values of burn severity (based on Key and Benson, 2006).

\begin{tabular}{|c|c|c|c|c|c|c|c|}
\hline \multirow[t]{3}{*}{ Strata rating factors } & \multicolumn{7}{|c|}{ Burn severity scale } \\
\hline & \multirow{2}{*}{$\begin{array}{l}\text { Unburned } \\
0\end{array}$} & \multicolumn{2}{|l|}{ Low } & \multicolumn{2}{|l|}{ Moderate } & \multicolumn{2}{|l|}{ High } \\
\hline & & 0.5 & 1 & 1.5 & 2 & 2.5 & 3 \\
\hline \multicolumn{8}{|l|}{ Substrate } \\
\hline $\begin{array}{l}\text { Litter/light fuel } \\
\text { consumed }\end{array}$ & None & $<10 \%$ & $10-20 \%$ & $20-40 \%$ & $40-80 \%$ & $80-98 \%$ & $98 \%$ \\
\hline Char \& colour & None & $\begin{array}{l}\text { Blackene } \\
\text { in soil }\end{array}$ & no changes & $\begin{array}{l}\text { Charred } \\
\text { remains, }\end{array}$ & ble litter & $\begin{array}{l}\text { Grey and white ash, grey } \\
\text { soil }\end{array}$ & $\begin{array}{l}\text { White ash, reddened } \\
\text { soil }\end{array}$ \\
\hline \multicolumn{8}{|l|}{ Vegetation $<1 \mathrm{~m}$} \\
\hline Foliage consumed & None & $<20 \%$ & $20-40 \%$ & $40-60 \%$ & $60-90 \%$ & $>90 \%$ & Branch loss \\
\hline \multicolumn{8}{|l|}{ Vegetation 1-5 m } \\
\hline Foliage consumed & None & $<10 \%$ & $10-30 \%$ & $30-60 \%$ & $60-95 \%$ & $>95 \%$ & Branch loss \\
\hline \multicolumn{8}{|l|}{ Vegetation 5-20 m } \\
\hline Green & $100 \%$ & $>90 \%$ & $70-90 \%$ & $50-70 \%$ & $10-50 \%$ & $<10 \%$ & None \\
\hline Black & None & $<5 \%$ & $5-20 \%$ & $20-40 \%$ & $40-85 \%$ & $>85 \%$ & No needles/leaves \\
\hline Brown & None & $<5 \%$ & $5-20 \%$ & $20-40 \%$ & $40-80 \%$ & $<40$ or $>80 \%$ & None \\
\hline Tree mortality & None & $<5 \%$ & $5-20 \%$ & $20-50 \%$ & $50-80 \%$ & $>80 \%$ & $100 \%$ \\
\hline Char height & None & $1 \mathrm{~m}$ & $1.5 \mathrm{~m}$ & $2 \mathrm{~m}$ & $2.8 \mathrm{~m}$ & $4 \mathrm{~m}$ & $>5 \mathrm{~m}$ \\
\hline \multicolumn{8}{|l|}{ Vegetation $>20 \mathrm{~m}$} \\
\hline Green & $100 \%$ & $>95 \%$ & $90-95 \%$ & $65-90 \%$ & $10-65 \%$ & $<10$ & None \\
\hline Black & None & $<5 \%$ & $5-10 \%$ & $10-35 \%$ & $35-80 \%$ & $>80 \%$ & No needles/leaves \\
\hline Brown & None & $<5 \%$ & $5-10 \%$ & $10-30 \%$ & $30-70 \%$ & $<30$ or $>70 \%$ & None \\
\hline Tree mortality & None & $<5 \%$ & $5-20 \%$ & $20-50 \%$ & $50-80 \%$ & $>80 \%$ & $100 \%$ \\
\hline Char height & None & $1 \mathrm{~m}$ & $1.8 \mathrm{~m}$ & $3 \mathrm{~m}$ & $4 \mathrm{~m}$ & $6 \mathrm{~m}$ & $>7 \mathrm{~m}$ \\
\hline
\end{tabular}




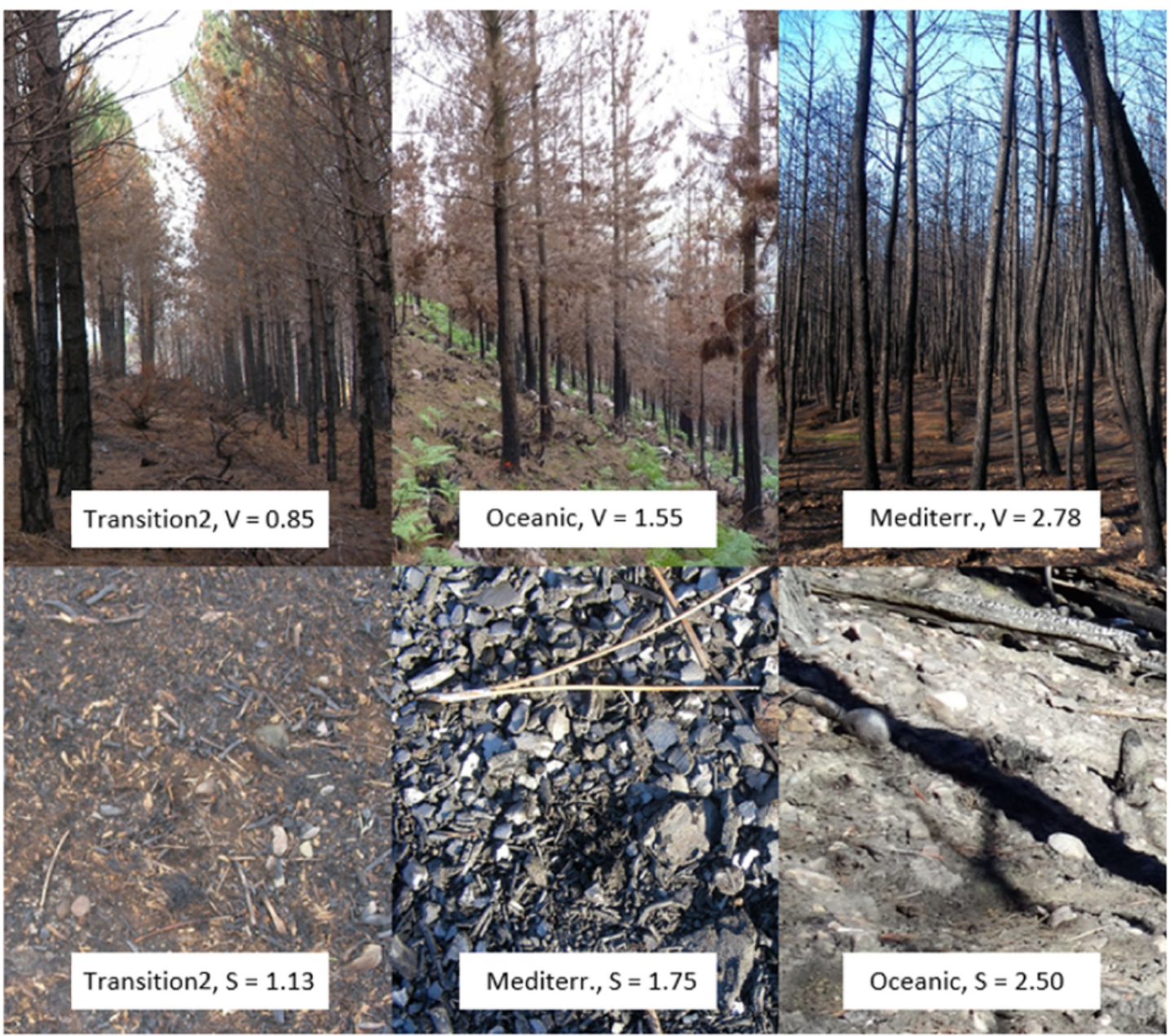

Fig. 3. Example of field plots and CBI values of vegetation burn severity (V) and soil burn severity (S).

study sites. The algorithms were chosen based on results by Lin et al. (2015) and Hantson and Chuvieco (2011). For each Landsat 7 reflective band, the land surface reflectance was transformed to comparable Landsat 8 surface reflectance according to the functions proposed by Roy et al. (2016).

Thermal band B10 (Landsat 8) or B6L (Landsat 7) was used to obtain the LST product, following the single channel method by the radiative transfer equation according Yu et al. (2014). The procedure (Fig. 1) comprises a radiometric calibration of the clipped image to converse DN to radiance with brightness temperature, atmospheric correction with emissivities adjustment, and conversion to temperature in Kelvin. To perform the atmospheric correction we applied the radiative transfer equation:

$$
\begin{aligned}
\mathrm{B}_{\mathrm{x}}\left(\mathrm{T}_{\mathrm{s}}\right) & =\left[\left(\mathrm{B}_{\mathrm{x}}\left(\mathrm{T}_{\mathrm{x}}\right)-\mathrm{I}_{\mathrm{x}}{ }^{\uparrow}\right) /\left(\varepsilon_{\mathrm{x}}\right.\right. \\
& \left.\left.* \tau_{\mathrm{x}}(\theta)\right)\right]-\left[\mathrm{I}_{\mathrm{x}}{ }^{\downarrow}\left(1-\varepsilon_{\mathrm{x}}\right) / \varepsilon_{\mathrm{x}}\right]
\end{aligned}
$$

$B_{x}\left(T_{s}\right)$ being the ground radiance received by the correspondent thermal band $\left(B_{x}\right), B_{x}\left(T_{x}\right)$ the radiance received by $B_{x}$ with brightness temperature $T_{x}, I^{\uparrow}$ and $I^{\downarrow}$ the upwelling and downwelling radiance respectively to $B_{x} \cdot \tau_{x}(\theta)$ is the atmospheric transmittance when the view zenith angle is $\theta$, and $\varepsilon_{\mathrm{x}}$ is surface emissivities for channel $\mathrm{x} . \mathrm{B}_{\mathrm{x}}\left(\mathrm{T}_{\mathrm{x}}\right)$ is obtained from $B_{x}$ radiance, $I_{x}{ }^{\uparrow}, I_{x}{ }^{\downarrow}$ and $\tau_{x}(\theta)$ were obtained from the National Centres for Environmental Prediction (NCEP) profiles provided by Barsi et al. (2005) on the ATMCORR tool (http://atmcorr. gsfc.nasa.gov/). $\varepsilon_{\mathrm{x}}$ was calculated using an NDVI thresholds method as follows:

$\varepsilon_{\mathrm{X}}$

$=\left\{\begin{array}{cr}0.973-\left(0.047 \rho_{\text {red }}\right) & \text { NDVI }<0.2 \\ 0.986 \mathrm{Pv}+0.967(1-\mathrm{Pv})+0.018(1-\mathrm{Pv}) & 0.2 \leq \mathrm{NDVI} \leq \\ 0.991 & \mathrm{NDVI}>0.5\end{array}\right.$

where $\rho_{\text {red }}$ is the reflectance of corrected B4 in Landsat 8 or B3 in Landsat 7, and Pv is calculated as follows:

$P v$
$=\left\{\begin{array}{cc}0 & {[(\mathrm{NDVI}-0.2) / 0.3]^{2}<0.2} \\ {[(\mathrm{NDVI}-0.2) / 0.3]^{2}} & 0.2 \leq[(\mathrm{NDVI}-0.2) / 0.3]^{2} \leq 0.5^{(} \\ 1 & {[(\mathrm{NDVI}-0.2) / 0.3]^{2}>0.5}\end{array}\right.$

Lastly, $\mathrm{B}_{\mathrm{x}}\left(\mathrm{T}_{\mathrm{s}}\right)$ radiance is transformed into LST (Kelvin) based on Planck's law using the following equation:

$\mathrm{LST}=\mathrm{K} 2_{\mathrm{x}} /\left(\ln \left(\left(\mathrm{K} 1_{\mathrm{x}} / \mathrm{B}_{\mathrm{x}}\left(\mathrm{T}_{\mathrm{s}}\right)\right)+1\right)\right)$

where $\mathrm{K} 1_{\mathrm{x}}$ and $\mathrm{K} 2_{\mathrm{x}}$ are thermal constants obtained from each image metadata for Landsat 8 and $666.09 \mathrm{~W} \mathrm{~m}^{-2} \mathrm{sr}^{-1} \mu \mathrm{m}^{-1}$ and $1282.71 \mathrm{~K}$ for Landsat 7 ETM +, respectively. 
In order to find the most suitable spectral indices to quantify burn severity in pine forests throughout the Mediterranean-Transition-Oceanic climatic gradient, we evaluated reflective, thermal and mixed (combining reflective and thermal) metrics sensitive to changes caused by fires. Indices were obtained from land surface reflectance $(\rho)$ or/and LST products of Landsat pre-processed bands following the algorithms included in Table 3. Specifically, we checked 13 spectral indices: 9 reflective indices (NBR, dNBR, RdNBR, RBR, NDVI, dNDVI, EVI, dEVI and dNBR-EVI), 2 thermal metrics (LST and dLST), and 2 mixed indices ((LST/EVI) and d(LST/EVI)).

We proposed the dNBR-EVI index as a potential improvement of traditional NBR-based indices for initial assessments of burn severity along climatic gradients, because its expected enhanced sensitivity to physical or bio-physical parameters such as: (1) the reflectance related to the internal structure of the leaves and the canopy density, retrieved by the NIR band (Key, 2006; Chuvieco, 2010; Veraverbeke et al., 2011), on which both components of the new index (dNBR and EVI) are supported; (2) the reflectance related to the moisture content of both vegetation and soil, retrieved by the SWIR band (Key, 2006; Chuvieco, 2010; Vlassova et al., 2014) of the dNBR component, but attenuated by the inclusion of the post-fire EVI for better transferability among climates; and (3) the reflectance related to the post-fire photosynthetic pigments, by the inclusion of Red and Blue bands (Gao et al., 2000; Chuvieco, 2010) from the EVI index, for better detection of senescent leaves in initial assessments. Furthermore, the dNBR-EVI combination attempts to solve the saturation problem of traditional NBR-based indices when estimating severely burned areas (e.g. Parks et al., 2014; Holden et al., 2010; Chen et al., 2011), by including the EVI index that has demonstrated not to be saturated (Holden et al., 2010; Chen et al., 2011).

Spectral indices values corresponding to each field plot were extracted by averaging the values of 175 sample points systematically distributed within each $30 \mathrm{~m}$ diameter plot, following the procedure of Picotte and Robertson (2011). We ensure that the number of points was representative according to accumulative adjustment curves.

\subsection{Data analysis}

The relationships between the field burn severity measurements (site burn severity, vegetation burn severity and soil burn severity) and the 13 remotely sensed metrics of burn severity were analysed along the climatic gradient (Mediterranean, Transition1, Transition2 and Oceanic sites) using ordinary least squares models. Although it is common to find non-linear relationships between CBI-based measurements and some remotely sensed metrics in the literature (Miller and Thode, 2007; Soverel et al., 2011; Cansler and McKenzie, 2012), we found a marginal improvement in the performance of models. Then, we graphi- cally checked the assumptions of homoscedasticity and normality of model residuals, and we decided to work with linear regression models, as other authors have done (e.g. Epting et al., 2005; De Santis and Chuvieco, 2009; Quintano et al., 2015). We considered the field burn severity measurements from each study site (Mediterranean, Transition and Oceanic) as dependent variables and the spectral indices as explanatory variables. The coefficient of determination $\left(R^{2}\right)$ and statistical significance $(p)$ of the regression models obtained fitting all the available plots were used to compare the performance of the spectral indices to each other in the same climatic region, and each index among the different climatic regions.

We analysed the transferability of the spectral indices-derived models using a cross validation "leave-one out" approach. Iteratively, models were trained using all the available plots of three wildfires, and validated using the plots of the remaining wildfire. The predictive accuracy of the models was assessed in each iteration by calculating the root mean squared error (RMSE) between observed and predicted values. RMSE values higher than $25 \%$ of the total range of the CBI $(0.75$ CBI points) were considered not acceptable (De Santis and Chuvieco, 2007).

In order to determine whether the coefficients of determination $\mathrm{R}^{2}$ and the RMSE values were statistically different among the analysed spectral indices, we performed analysis of variance of linear mixed models (LMMs) including the study site as random factor. Fisher's LSD test was applied to specify which of the means were significantly different.

All statistical analyses were performed using R (R Core Team, 2016). nlme (Pinheiro et al., 2017) and multcomp (Hothorn et al., 2017) packages were used.

\section{Results}

\subsection{Relationship between field burn severity and spectral indices}

We found a common trend in the behaviour of the spectral indices that were, in general, highly suitable to correlate site (Table 4) and vegetation (Table 5) burn severity, but not so able to match soil burn severity (Table 6).

The results of the site burn severity (Table 4) indicated that the proposed new index dNBR-EVI and the other differenced reflective indices based on NBR (dNBR, RdNBR and RBR), showed significantly better correlations than thermal and mixed metrics along the climatic gradient. The new index showed the best fit in the Mediterranean $\left(\mathrm{R}^{2}=0.82\right)$ and Oceanic $\left(\mathrm{R}^{2}=0.78\right)$ sites. The rest of the indices showed a significantly worse performance to match site burn severity along the entire gradient. In particular, NDVI and dNDVI did not work well in the Mediterranean region $\left(\mathrm{R}^{2} \leq 0.28\right)$, and thermal metrics (LST

Table 3

Selected indices and calculation algorithm, using Landsat 8 OLI/TIRS bands or Landsat 7 ETM + bands.

\begin{tabular}{|c|c|c|c|c|}
\hline Spectral index & & Landsat 8 OLI/TIRS formula & Landsat 7 ETM + formula & Reference \\
\hline \multirow[t]{9}{*}{ Reflective } & NBR & $\left(\rho_{5}-\rho_{7}\right) /\left(\rho_{5}+\rho_{7}\right)$ & $\left(\rho_{4}-\rho_{7}\right) /\left(\rho_{4}+\rho_{7}\right)$ & López-García and Caselles (1991) \\
\hline & dNBR & $1000\left(\mathrm{NBR}_{\text {pre }}-\mathrm{NBR}_{\text {post }}\right)-$ offset $^{\mathrm{a}}$ & $1000\left(\mathrm{NBR}_{\text {pre }}-\mathrm{NBR}_{\text {post }}\right)-$ offset $^{\mathrm{a}}$ & Key (2006) \\
\hline & RdNBR & $\mathrm{dNBR} /\left(\left|\mathrm{NBR}_{\mathrm{pre}}\right|^{0.5}\right)$ & $\mathrm{dNBR} /\left(\left|\mathrm{NBR}_{\text {pre }}\right|^{0.5}\right)$ & Miller and Thode (2007) \\
\hline & RBR & $\mathrm{dNBR} /\left(\mathrm{NBR}_{\mathrm{pre}}+1.001\right)$ & $\mathrm{dNBR} /\left(\mathrm{NBR}_{\mathrm{pre}}+1.001\right)$ & Parks et al. (2014) \\
\hline & NDVI & $\left(\rho_{5}-\rho_{4}\right) /\left(\rho_{5}+\rho_{4}\right)$ & $\left(\rho_{4}-\rho_{3}\right) /\left(\rho_{4}+\rho_{3}\right)$ & Rouse et al. (1973) \\
\hline & dNDVI & $\mathrm{NDVI}_{\text {pre }}-\mathrm{NDVI}_{\text {post }}$ & $\mathrm{NDVI}_{\text {pre }}-\mathrm{NDVI}_{\text {post }}$ & Zhu et al. (2006) \\
\hline & EVI & $2.5\left[\left(\rho_{5}-\rho_{4}\right) /\left(\rho_{5}+6 \rho_{4}-7.5 \rho_{2}+1\right)\right]$ & $2.5\left[\left(\rho_{4}-\rho_{3}\right) /\left(\rho_{4}+6 \rho_{3}-7.5 \rho_{1}+1\right)\right]$ & Gao et al. (2000) \\
\hline & dEVI & $\mathrm{EVI}_{\text {pre }}-\mathrm{EVI}_{\text {post }}$ & $\mathrm{EVI}_{\text {pre }}-\mathrm{EVI}_{\text {post }}$ & Zhu et al. (2006) \\
\hline & dNBR-EVI & $($ dNBR-EVI $* 1000)-$ offset $^{\mathrm{a}}$ & $(\mathrm{dNBR}-E V I * 1000)-$ offset $^{\mathrm{a}}$ & Proposed by the authors \\
\hline \multirow[t]{2}{*}{ Thermal } & LST & LST in Kelvin from $B_{10}\left(T_{s}\right)$ & LST in Kelvin from $B_{6 L}\left(T_{s}\right)$ & Yu et al. (2014) \\
\hline & dLST & $\mathrm{LST}_{\text {post }}-\mathrm{LST}_{\text {pre }}$ & $\mathrm{LST}_{\text {post }}-\mathrm{LST}_{\text {pre }}$ & Zheng et al. (2016) \\
\hline \multirow[t]{2}{*}{ Mixed } & LST/EVI & $(\mathrm{LST}-273.15) / \mathrm{EVI}$ & $(\mathrm{LST}-273.15) / \mathrm{EVI}$ & Zheng et al. (2016) \\
\hline & $\mathrm{d}(\mathrm{LST} / \mathrm{EVI})$ & $(\mathrm{LST} / \mathrm{EVI})_{\mathrm{post}}-(\mathrm{LST} / \mathrm{EVI})_{\mathrm{pre}}$ & $(\mathrm{LST} / \mathrm{EVI})_{\mathrm{post}}-(\mathrm{LST} / \mathrm{EVI})_{\mathrm{pre}}$ & Zheng et al. (2016) \\
\hline
\end{tabular}

a Offset is the average index value from pixels in homogeneous and unchanged areas. 
Table 4

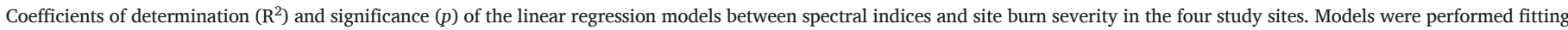
all the available plots from each study site.

\begin{tabular}{|c|c|c|c|c|c|c|}
\hline \multicolumn{2}{|c|}{ Spectral index } & \multicolumn{5}{|c|}{ Site burn severity } \\
\hline & & M & $\mathrm{T} 1$ & $\mathrm{~T} 2$ & $\mathrm{O}$ & Mean \pm SD \\
\hline \multirow[t]{9}{*}{ Reflective } & dNBR-EVI & $0.82 \cdots$ & $0.87^{\cdots}$ & $0.87 \cdots$ & 0.78 & $0.84 \pm 0.04 a$ \\
\hline & NBR & $0.62 \cdots$ & $0.75^{\cdots}$ & $0.88^{\cdots}$ & $0.62 \cdots$ & $0.72 \pm 0.12 \mathrm{ac}$ \\
\hline & dNBR & $0.79 \cdots$ & $0.88^{\cdots}$ & $0.86^{\cdots}$ & $0.69 \cdots$ & $0.81 \pm 0.09 \mathrm{ab}$ \\
\hline & RdNBR & $0.76 \cdots$ & $0.83^{\cdots}$ & $0.89 \cdots$ & $0.68^{\cdots}$ & $0.79 \pm 0.09 a b$ \\
\hline & RBR & $0.77^{\cdots}$ & $0.88^{\cdots}$ & $0.88^{\cdots}$ & $0.68^{\cdots}$ & $0.80 \pm 0.10 \mathrm{ab}$ \\
\hline & NDVI & 0.02 & $0.69 \cdots$ & $0.54 \cdots$ & $0.51^{\cdots}$ & $0.44 \pm 0.29 \mathrm{e}$ \\
\hline & dNDVI & $0.28 \cdots$ & $0.76^{\cdots}$ & $0.69 \cdots$ & $0.58 \cdots$ & $0.58 \pm 0.21$ ce \\
\hline & EVI & $0.59 \cdots$ & $0.68^{\cdots}$ & $0.63^{\cdots}$ & $0.69 \cdots$ & $0.65 \pm 0.05 \mathrm{bcd}$ \\
\hline & dEVI & $0.53 \cdots$ & $0.66^{\cdots}$ & $0.37^{\cdots}$ & $0.69 \cdots$ & $0.56 \pm 0.15$ ce \\
\hline \multirow[t]{2}{*}{ Thermal } & LST & $0.31^{\cdots}$ & $0.66^{\cdots}$ & $0.65^{\cdots}$ & $0.21^{*}$ & $0.46 \pm 0.23 \mathrm{e}$ \\
\hline & dLST & $0.54 \cdots$ & $0.80^{\cdots}$ & $0.77^{\cdots}$ & 0.24 & $0.59 \pm 0.26$ ce \\
\hline \multirow[t]{2}{*}{ Mixed } & LST/EVI & $0.56^{\cdots}$ & $0.51^{\cdots}$ & $0.50 \cdots$ & $0.44^{\cdots}$ & $0.50 \pm 0.05 \mathrm{de}$ \\
\hline & d(LST/EVI) & $0.59 \cdots$ & $0.53^{\cdots}$ & $0.51^{\cdots}$ & $0.43^{\cdots}$ & $0.52 \pm 0.07 \mathrm{de}$ \\
\hline
\end{tabular}

M: Mediterranean site, T1: Transition1 site, T2: Transition2 site, O: Oceanic site.

Significances of the correlations are represented as ., $\cdot$ and $\cdots(p<0.05, p<0.01$, and $p<0.001$, respectively).

Letters ( $\mathrm{a}, \mathrm{b}, \mathrm{c}, \mathrm{d}, \mathrm{e}$ ) indicate significant differences among mean $\mathrm{R}^{2}$ values of the spectral indices.

Table 5

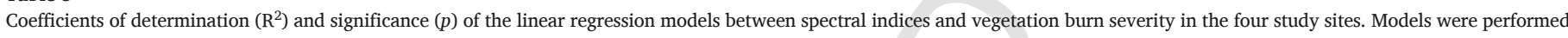
fitting all the available plots from each study site.

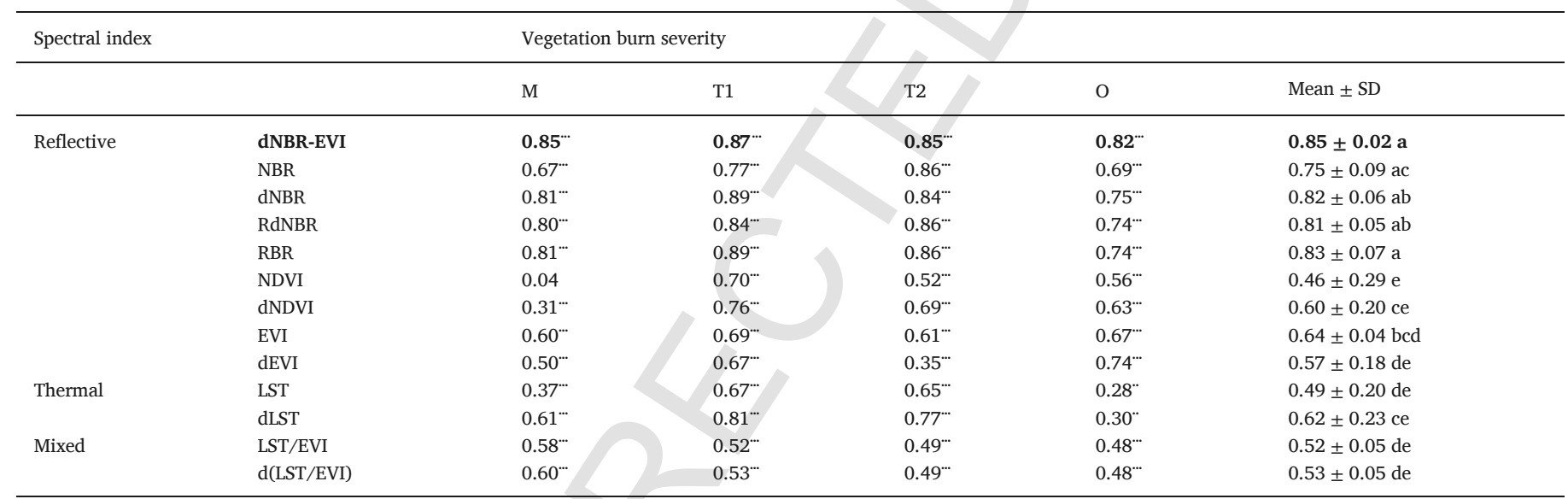

M: Mediterranean site, T1: Transition1 site, T2: Transition2 site, O: Oceanic site.

Significances of the correlations are represented as $\cdot, \cdot \cdot$ and $\cdots(\mathrm{p}<0.05, \mathrm{p}<0.01$, and $\mathrm{p}<0.001$, respectively).

Letters ( $\mathrm{a}, \mathrm{b}, \mathrm{c}, \mathrm{d}, \mathrm{e}$ ) indicate significant differences among mean $\mathrm{R}^{2}$ values of the spectral indices.

and dLST) did not work in the Oceanic region $\left(\mathrm{R}^{2} \leq 0.24\right)$. Mixed indices [LST/EVI and d(LST/EVI)], were outperformed along the climatic gradient by reflective indices based on NBR and by EVI.

Focusing on vegetation burn severity (Table 5), there were similar fits and patterns as on site burn severity along the climatic gradient. Therefore, reflective NBR based indices (NBR, dNBR, RdNBR and RBR) and EVI were the best fitted along the entire climatic gradient, although the dNBR-EVI index was the best fitted $\left(R^{2} \geq 0.82\right)$.

The analysed spectral indices did not correlate soil burn severity as well as site or vegetation burn severity (Table 6). Reflective indices based on NBR reached the highest $\mathrm{R}^{2}$ values, being significantly better than thermal and mixed indices, dNBR-EVI being the best one. Thermal metrics reached relatively high values of the coefficient of determination in the Transition region $\left(R^{2} \geq 0.54\right)$, but a non-significant relation was found in the Oceanic region. Mixed indices did not reach high values in any climatic region $\left(R^{2} \leq 0.45\right)$.

The dNBR-EVI outperformed the previously existing indices in most situations, and was the only index whose coefficients of determination were significantly higher than vegetation reflective indices (NDVI, dNDVI, EVI and dEVI), thermal metrics and mixed indices when matching the site, vegetation and soil burn severity. Furthermore, regressions between dNBR-EVI and field measurements of burn severity (Fig. 4) showed that dNBR-EVI index did not have saturation-related problems in high severity scenarios, as occurs with the other NBR-based indices.

\subsection{Transferability of spectral indices-derived models to predict burn severity}

Cross-validation showed the highest accuracies when predicting the site burn severity (Table 7), little differences with vegetation (Table 8) and soil burn severity (Table 9) being observed. Broadly, errors were higher when predicting burn severity in the Transition1 and Oceanic sites.

Analysing the transferability of spectral indices-derived models to predict the site burn severity (Table 7) along the entire climatic gradient, we found that the dNBR-EVI-based models reached the lowest RMSE values (RMSE $\leq 0.47$ ), being significantly better than vegetation (RMSE $\geq 0.60$ ), thermal (RMSE $\geq 0.70$ ) and mixed (RMSE $\geq 0.63$ ) indices. Only models based on differenced NBR-type indices reached ad- 
Table 6

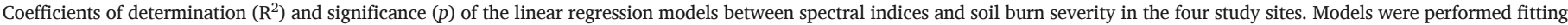
all the available plots from each study site.

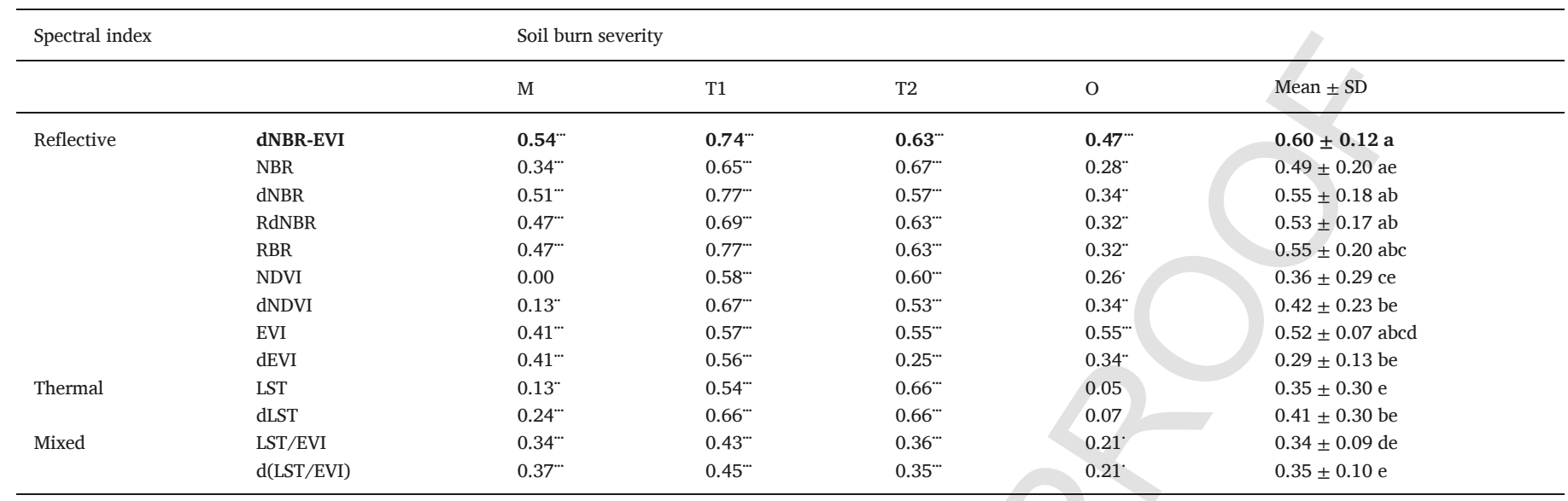

M: Mediterranean site, T1: Transition1 site, T2: Transition2 site, O: Oceanic site.

Significances of the correlations are represented as ., $\cdot$ and $\cdots(\mathrm{p}<0.05, \mathrm{p}<0.01$, and $\mathrm{p}<0.001$, respectively).

Letters ( $a, b, c, d, e)$ indicate significant differences among mean $R^{2}$ values of the spectral indices.

missible RMSE values ( $\leq 25 \%$ of the CBI range) along the entire gradient. Focusing on the rest of the metrics, predictions of models based on vegetation indices worked better on the humid side of the gradient, particularly in the Oceanic site.

Focusing on vegetation burn severity (Table 8), models showed very similar patterns to site burn severity, being the dNBR-EVI the most transferable index along the climatic gradient. RMSE values of vegetation, thermal and mixed indices were inadmissible ( $>25 \%$ of the CBI range) in most scenarios.

Predictions of soil burn severity (Table 9) indicated that the dNBR-EVI-derived models were the most accurate and transferable along the climatic gradient. RMSE values of predictions based on the other indices were not acceptable (RMSE $>0.75$ ) in at least one study site, except for dEVI. The EVI-based model showed a good ability when predicting the soil burn severity in the Oceanic site.

\section{Discussion}

Reflective spectral indices are the best matched to field measurements of burn severity based on CBI in pine forests in the three climatic regions. Specifically, indices using NIR and SWIR or indices combining Red and Blue worked better than thermal and mixed metrics, on the one hand correlating better the field burn severity measurements, and on the other hand being more transferable among climatic regions. Both thermal and mixed indices showed worse performance and greater variability among regions. Another feature confirmed in this study is the limitation of remotely sensed indices to correlate soil burn severity, probably due to the shielding effect of vegetation or their remains (Soverel et al., 2011; Tanase et al., 2011), corroborating results found by other authors when analysing the remote sensing of burn severity on understory (Key, 2006; Cansler and McKenzie, 2012; Wu et al., 2015).

Reflective indices based on NBR (NBR, dNBR, RdNBR and RBR) showed good behaviour in Mediterranean and Transition environments, reaching good relationships with field measurements of burn severity similar to or even better than those reported in other wildfires (Zhu et al., 2006; Miller and Thode, 2007; Veraverbeke et al., 2010; Tanase et al., 2011; Parks et al., 2014) and their models showed a high transferability for site burn severity predictions as other authors found (Soverel et al., 2011). The sensitivity of these indices to burn severity is widely recognized (e.g. Miller et al., 2009; Chu and Guo, 2014; Fernández-Manso and Quintano, 2015), and it is due to the decrease in
NIR reflectance, sensitive to the cellular structure of the leaves, and the simultaneous increase in SWIR reflectance primarily related to decreased moisture content (Key, 2006; De Santis and Chuvieco, 2007; Miller and Thode, 2007; Robichaud et al., 2007; Chuvieco, 2010; Veraverbeke et al., 2011; Harris et al., 2011; Cansler and McKenzie, 2012). The dNBR and the relativized indices RdNBR and RBR produced similar regression fits and predictive errors, a result which can be attributed to the high homogeneity of the studied ecosystems (Miller and Thode, 2007). Analysing the models along the climatic gradient, despite the good performance of reflective indices based on NBR in Mediterranean and Transition regions, our results demonstrate more difficulties in correlating and predicting $\mathrm{CBI}$ in the Oceanic region. Other studies can support the idea that climate-related factors have an important effect on the performance of these indices. Thus, Zhu et al. (2006) found the worst fit for dNBR in the Northern Rockies, with a humid climate $\left(\mathrm{R}^{2}=0.65\right)$, and much better results in Mediterranean and arid zones ( $\mathrm{R}^{2}$ from 0.72 to 0.79 ). Also Parks et al. (2014) found the best performance of dNBR-based indices in the Southwestern US, with a relatively dry climate. Soverel et al. (2011) related the lower $\mathrm{R}^{2}$ values ( 0.40 to 0.50 ) in some of their study regions to the high soil moisture content, which is a potential facilitator of decoupled fires (fires with different burn severity levels per strata). A single index does not capture this decoupling among strata because it provides an overall value not segregated by strata, leading in worse correspondences (Tanase et al., 2011). Another potential cause of the worse performance in the Oceanic region related to soil moisture is its high absorbance of SWIR radiation (Chuvieco, 2010; Vlassova et al., 2014). Consequently, the expected increase in SWIR reflectance after fire may be attenuated in Oceanic sites, especially in the highest burn severity areas, where soils can play a major role in the satellite received reflectance because of the depletion of the vegetation layer (Robichaud et al., 2007; Chuvieco, 2010). These hypotheses are supported by the mean SWIR reflectance values obtained within the fire perimeters in the post-fire image, being lower in the Oceanic study site $(3.14 \pm 1.64)$ than in the other wildfires $(\geq 4.50)$. Furthermore, areas with a humid climate can have faster post-fire green-up (Soverel et al., 2011; Liu, 2016; Rother and Veblen, 2017), rapidly reducing the change in reflectance values caused by burn severity. This influence of climate could be greatest in extended assessments, when the apparent magnitude of the initial burn severity is decreased (Key and Benson, 2006).

The analysed reflective vegetation indices (NDVI, dNDVI, EVI and $\mathrm{dEVI}$ ) showed very different results when correlating burn severity, as 

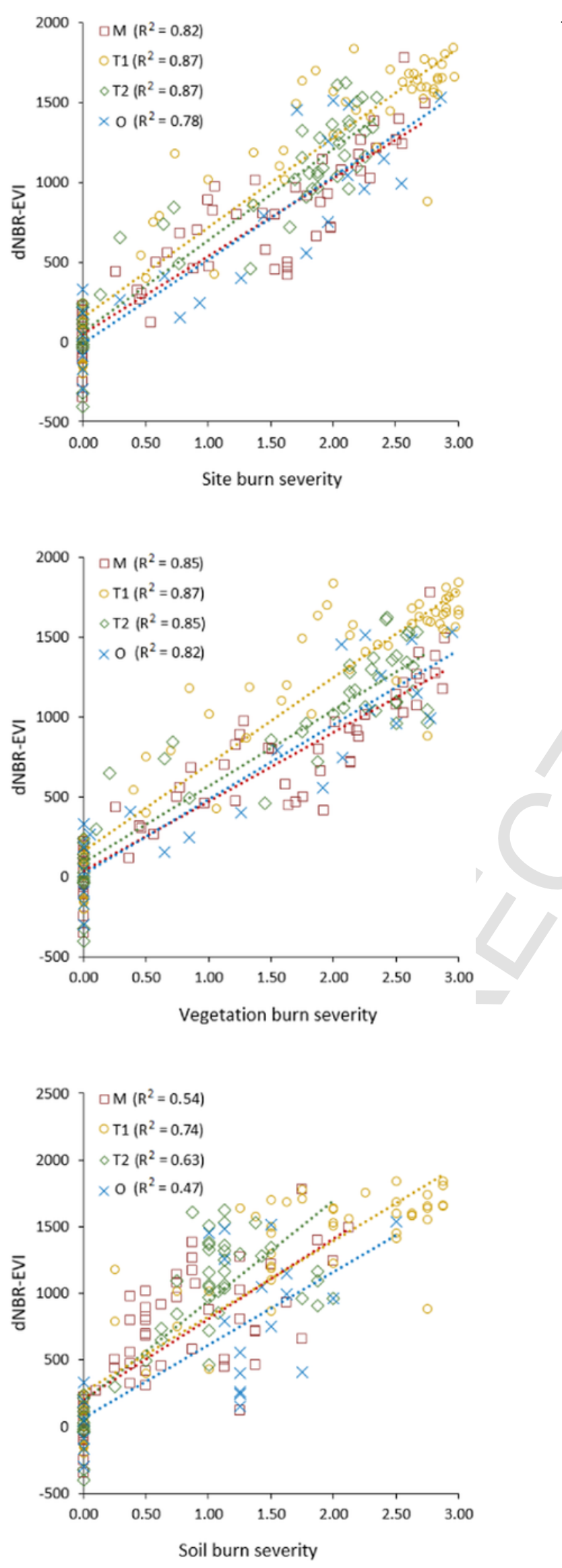

? Fig. 4. Linear relationships between spectral index dNBR-EVI and each field measurement of burn severity (site, vegetation and soil burn severity). Study sites are represented as M (Mediterranean), T1 (Transition1), T2 (Transition2) and O (Oceanic).

they did when extrapolating their models to new study sites. Their response is based on the reflectance of the Red band, which is higher when the vegetation is stressed, and also in the NIR reflectance, which has an opposite response to Red (Gao et al., 2000; Huete et al., 2002; Chuvieco, 2010). However, although both kinds of indices (NDVI and EVI) are highly sensitive to chlorophyll levels, EVI is more related to structural characteristics of vegetation, such as leaf area or plant canopy and architecture of the vegetation (Huete et al., 2002). NDVI and dNDVI showed a great variability along the climatic gradient, and they did not work in the Mediterranean region, maybe due to the higher effect of summer drought on chlorophyll levels than in other indices like EVI (Mänd et al., 2010) and because, in general, the pigment content per leaf area decreases with climate aridity (Madani et al., 2017; Yudina et al., 2017) as the NDVI of the fire scars revealed in the pre-fire images (from $0.38 \pm 0.09$ in the Oceanic site to $0.31 \pm 0.09$ in the Mediterranean site). Thus, it is very likely that the NDVI and dNDVI indices confused severity levels and burned areas with low activity zones in Mediterranean regions, where the drought period is usually coincident to the fire occurrence period (Steel et al., 2015). For this reason, greenness immediately before the fire could be lower than values from the pre-fire images. This possibility was previously reported by Picotte and Robertson (2011). Conversely, EVI relationships with field burn severity were relatively as good as could be expected (Harris et al., 2011; Wu et al., 2015; Zheng et al., 2016), principally in the Oceanic region. EVI is a robust index against changes of soil type and atmosphere because it includes the Blue band and two coefficients, unlike the NDVI, which is also less consistent in time (Gao et al., 2000; Chuvieco, 2010). Furthermore, the Red band can detect senescent leaves (Chuvieco, 2010; Mänd et al., 2010), which is advantageous information for initial burn severity assessments, when the delayed tree mortality detection is challenging (Key and Benson, 2006). The worse transferability of the EVI-based models to the Transition 1 site (Landsat 7 imagery) could be due to the lower correlation between Blue bands than between the other reflective bands from ETM + and OLI sensors (Roy et al., 2016).

Thermal metrics (LST and dLST) did not work in the same way along the climatic gradient. The highest coefficients of determination of the thermal metrics were reached in the Transition region, obtaining similar results to those reported in other wildfires (Quintano et al., 2015, Zheng et al., 2016). However, these indices did not work as well in the other two regions. The variable performance of thermal metrics in the different study sites could lead to unacceptable predictions (RMSE > 0.75) in most scenarios when extrapolating LST-based models along the climatic gradient, suggesting that models have to be performed in each single fire. These differences may be due to the influence of topographic factors in the LST generating changes not related to burn severity. Aspect and altitudinal differences strongly affect LST (Vlassova et al., 2014; Quintano et al., 2015), and these topographic parameters have a large variation in the Mediterranean and Oceanic sites. Another factor that could affect the operation of thermal metrics along the climatic gradient could be moisture, which is higher in the Oceanic region. Chuvieco (2010) indicates that moisture content is one of the most outstanding factors in the thermal behaviour of soils. Thus, higher moisture content in soil and above the surface, could soften the LST differences caused by the burn severity. Besides, assorted aspects lead to differences in moisture (Wu et al., 2013). In brief, homogeneity in topography and moisture in the Transition sites, where thermal metrics are some of the best to assess soil burn severity, can explain the widely better results obtained in this sites in comparison to the other study areas. For extended assessments, it is necessary to take into ac- 
Table 7

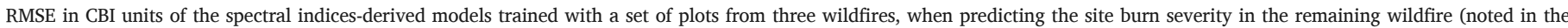
heading of the table).

\begin{tabular}{|c|c|c|c|c|c|c|}
\hline \multirow[t]{2}{*}{ Spectral index } & & \multicolumn{5}{|c|}{ Site burn severity } \\
\hline & & M & $\mathrm{T} 1$ & $\mathrm{~T} 2$ & $\mathrm{O}$ & Mean \pm SD \\
\hline \multirow[t]{9}{*}{ Reflective } & dNBR-EVI & 0.41 & 0.41 & 0.34 & 0.47 & $0.41 \pm 0.05 a$ \\
\hline & NBR & 0.59 & 0.85 & 0.37 & 0.83 & $0.66 \pm 0.23 b c$ \\
\hline & dNBR & 0.43 & 0.51 & 0.49 & 0.58 & $0.50 \pm 0.06 \mathrm{ab}$ \\
\hline & RdNBR & 0.46 & 0.52 & 0.32 & 0.67 & $0.49 \pm 0.15 a b$ \\
\hline & RBR & 0.44 & 0.38 & 0.35 & 0.65 & $0.46 \pm 0.14 \mathrm{ab}$ \\
\hline & NDVI & 0.97 & 0.83 & 0.64 & 0.81 & $0.81 \pm 0.14$ cde \\
\hline & dNDVI & 0.79 & 0.71 & 0.60 & 0.67 & $0.69 \pm 0.08 \mathrm{bd}$ \\
\hline & EVI & 0.87 & 1.45 & 0.72 & 0.60 & $0.91 \pm 0.38 \mathrm{de}$ \\
\hline & dEVI & 0.71 & 1.29 & 0.76 & 0.69 & $0.86 \pm 0.29$ cde \\
\hline \multirow[t]{2}{*}{ Thermal } & LST & 0.79 & 0.98 & 0.90 & 0.94 & $0.90 \pm 0.08 \mathrm{de}$ \\
\hline & dLST & 0.91 & 0.70 & 0.84 & 0.84 & $0.82 \pm 0.09$ cde \\
\hline \multirow[t]{2}{*}{ Mixed } & LST/EVI & 0.80 & 1.39 & 1.01 & 0.78 & $1.00 \pm 0.28 \mathrm{e}$ \\
\hline & $\mathrm{d}(\mathrm{LST} / \mathrm{EVI})$ & 0.63 & 0.85 & 0.96 & 0.74 & $0.80 \pm 0.14 \mathrm{cde}$ \\
\hline
\end{tabular}

M: Mediterranean site, T1: Transition1 site, T2: Transition2 site, O: Oceanic site.

Letters (a, b, c, d, e) indicate significant differences among mean RMSE values of the spectral indices.

Table 8

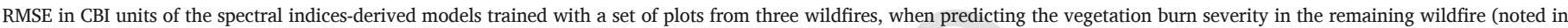
the heading of the table).

\begin{tabular}{|c|c|c|c|c|c|c|}
\hline \multicolumn{2}{|c|}{ Spectral index } & \multicolumn{5}{|c|}{ Vegetation burn severity } \\
\hline & & M & $\mathrm{T} 1$ & $\mathrm{~T} 2$ & $\mathrm{O}$ & Mean \pm SD \\
\hline \multirow[t]{9}{*}{ Reflective } & dNBR-EVI & 0.47 & 0.53 & 0.42 & 0.49 & $0.48 \pm 0.05 a$ \\
\hline & NBR & 0.66 & 1.07 & 0.52 & 0.86 & $0.78 \pm 0.24 \mathrm{bc}$ \\
\hline & dNBR & 0.45 & 0.42 & 0.51 & 0.59 & $0.49 \pm 0.08 \mathrm{a}$ \\
\hline & RdNBR & 0.52 & 0.71 & 0.43 & 0.70 & $0.59 \pm 0.14 \mathrm{ab}$ \\
\hline & RBR & 0.48 & 0.45 & 0.41 & 0.66 & $0.50 \pm 0.11 \mathrm{a}$ \\
\hline & NDVI & 1.09 & 0.85 & 0.77 & 0.85 & $0.89 \pm 0.14 \mathrm{~cd}$ \\
\hline & dNDVI & 0.89 & 0.64 & 0.66 & 0.71 & $0.73 \pm 0.11 \mathrm{ac}$ \\
\hline & EVI & 0.94 & 1.50 & 0.81 & 0.70 & $0.99 \pm 0.36 \mathrm{~cd}$ \\
\hline & dEVI & 0.85 & 1.62 & 0.95 & 0.80 & $1.06 \pm 0.38 \mathrm{~d}$ \\
\hline \multirow[t]{2}{*}{ Thermal } & LST & 0.85 & 0.91 & 0.96 & 1.02 & $0.94 \pm 0.07 \mathrm{~cd}$ \\
\hline & dLST & 1.07 & 0.64 & 0.84 & 0.92 & $0.87 \pm 0.18 \mathrm{~cd}$ \\
\hline \multirow[t]{2}{*}{ Mixed } & LST/EVI & 0.86 & 1.39 & 1.16 & 0.86 & $1.07 \pm 0.26 \mathrm{~d}$ \\
\hline & $\mathrm{d}(\mathrm{LST} / \mathrm{EVI})$ & 0.72 & 0.81 & 1.01 & 0.81 & $0.84 \pm 0.12 \mathrm{bcd}$ \\
\hline
\end{tabular}

M: Mediterranean site, T1: Transition1 site, T2: Transition2 site, O: Oceanic site.

Letters (a, b, c, d) indicate significant differences among mean RMSE values of the spectral indices.

Table 9

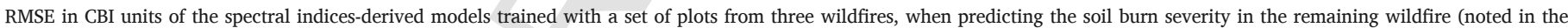
heading of the table).

\begin{tabular}{|c|c|c|c|c|c|c|}
\hline \multicolumn{2}{|c|}{ Spectral index } & \multicolumn{5}{|c|}{ Soil burn severity } \\
\hline & & M & $\mathrm{T} 1$ & $\mathrm{~T} 2$ & $\mathrm{O}$ & Mean \pm SD \\
\hline \multirow[t]{9}{*}{ Reflective } & dNBR-EVI & 0.45 & 0.71 & 0.48 & 0.61 & $0.56 \pm 0.12 a$ \\
\hline & NBR & 0.52 & 0.80 & 0.37 & 0.89 & $0.65 \pm 0.24$ acd \\
\hline & $\mathrm{dNBR}$ & 0.54 & 0.90 & 0.62 & 0.68 & $0.69 \pm 0.15 \mathrm{ae}$ \\
\hline & RdNBR & 0.49 & 0.71 & 0.51 & 0.76 & $0.62 \pm 0.14 \mathrm{ac}$ \\
\hline & RBR & 0.51 & 0.76 & 0.45 & 0.74 & $0.62 \pm 0.16 \mathrm{ac}$ \\
\hline & NDVI & 0.77 & 1.01 & 0.45 & 0.86 & $0.77 \pm 0.24$ bce \\
\hline & dNDVI & 0.65 & 0.98 & 0.61 & 0.67 & $0.73 \pm 0.17 \mathrm{ae}$ \\
\hline & EVI & 0.82 & 1.35 & 0.60 & 0.52 & $0.82 \pm 0.37 \mathrm{de}$ \\
\hline & dEVI & 0.49 & 0.67 & 0.52 & 0.65 & $0.58 \pm 0.09 \mathrm{ab}$ \\
\hline \multirow[t]{2}{*}{ Thermal } & LST & 0.71 & 1.15 & 0.73 & 0.81 & $0.85 \pm 0.20 \mathrm{e}$ \\
\hline & dLST & 0.57 & 0.96 & 0.85 & 0.72 & $0.78 \pm 0.17$ bce \\
\hline \multirow[t]{2}{*}{ Mixed } & LST/EVI & 0.75 & 1.36 & 0.69 & 0.66 & $0.87 \pm 0.33 \mathrm{e}$ \\
\hline & d(LST/EVI) & 0.56 & 1.04 & 0.91 & 0.68 & $0.80 \pm 0.22$ ce \\
\hline
\end{tabular}

M: Mediterranean site, T1: Transition1 site, T2: Transition2 site, O: Oceanic site.

Letters (a, b, c, d, e) indicate significant differences among mean RMSE values of the spectral indices. 
count that differences in LST due to burn severity rapidly decrease with the time-lapse after fire (Quintano et al., 2015).

Indices that combine thermal and optical bands (LST/EVI and dLST/ EVI) performed better than thermal metrics at the ends of the gradient, and worse in the Transition region. They did not exceed optical indices such as mono-temporal or bi-temporal NBR, and they showed little transferability since they exceeded the assumable error in many scenarios. Our coefficients of determination coincided with those obtained in previous research works in Western United States (Zheng et al., 2016), although these authors obtained higher $\mathrm{R}^{2}$ in mixed indices than in reflective and thermal ones. Similarly, Harris et al. (2011) proposed the use of indices based on reflective and thermal bands that were well correlated to ground measured burn severity.

The new proposed index, dNBR-EVI, showed the best performance along the climatic gradient. First, the dNBR-EVI reached the highest $\mathrm{R}^{2}$ values when matching the three field measurements of burn severity (site, vegetation and soil burn severity). Additionally, its models showed the highest transferability along the climatic gradient, being the only analysed index with admissible predictions in all studied scenarios (RMSE $\leq 0.75$ ). Particularly, the new index has proven to be a large improvement in the assessment of soil burn severity, which was the most difficult variable to be detected by the spectral indices. The new index also constituted an enhancement in burn severity detection in the Oceanic region (site, vegetation and soil burn severity), the study site where the other NBR-based indices performed the worst. The better performance of the new index in comparison with the others analysed may be due to several reasons: (1) The dNBR-EVI regression did not show signal saturation at high severities, a common problem when using dNBR, RdNBR or RBR (De Santis et al., 2010; Veraverbeke et al., 2012; Parks et al., 2014). This is a significant improvement when predicting high burn severity patches, because those are the areas where the recovery of vegetation and soil may be endangered (Calvo et al., 2008; Fernández and Vega, 2016; González-de-Vega et al., 2016), and consequently, they are targets for forest managers (Miller and Thode, 2007). (2) dNBR-EVI uses more spectral information than the other NBR type indices, combining Red, Blue, NIR and SWIR bands, which are meaningful for initial burn severity assessments along climatic gradients due to their respective sensitivity to atmospheric aerosols, chlorophyll levels, cellular structure of the leaves and canopy density, and soil and vegetation moisture (Huete et al., 2002; Key, 2006; Chuvieco, 2010; Cansler and McKenzie, 2012). (3) In the calculation of the dNBR-EVI, the contribution of the SWIR band is less important than in the other NBR type indices. As SWIR reflectance is closely related to moisture content (Veraverbeke et al., 2011; Harris et al., 2011; Cansler and McKenzie, 2012), the dNBR-EVI index could be more robust dealing with moisture variability, typical in climatic gradients. (4) The dNBR-EVI index combines the bi-temporal approach by including the dNBR, and the mono-temporal perspective provided by the post-fire EVI. Thus, the new index has the advantage of a high model fit, characteristic of bi-temporal NBR-based indices, with the influence of a mono-temporal index that can lead to more scatter in the unburned areas. However, the mono-temporal component compensates for differences in vegetation phenology (Veraverbeke et al., 2010) or hydrological fluctuations (Picotte and Robertson, 2011) between the pre and post-fire scenes.

Our results demonstrate that the new dNBR-EVI index is very suitable for use in initial burn severity assessments of pine forests across different climatic regions. Thus, several issues should be taken into account when applying it under different circumstances, such as extended assessments, different ecosystems or different geographical regions. In this study we analysed the performance of spectral indices for initial burn severity assessments, because in the Mediterranean countries interventions are usually carried out within the first year after fire, extended assessments being less appropriate (Tanase et al., 2011).
However, extended assessments are widely used in other regions of the world (Miller and Thode, 2007; Miller et al., 2009; Parks et al., 2014; Zheng et al., 2016), so the dNBR-EVI performance should be analysed considering that spectral response is highly dependent on the time lapse after fire (Chen et al., 2011; Quintano et al., 2015; Meddens et al., 2016). Further validations are also recommended when extrapolating the new index to ecosystems with different species composition, since the spectral signature of each kind of forest is different (Lehmann et al., 2015). We also highlight the importance of further research in different geographic regions, because they are linked to different climates and ecosystems, and they have an influence on spectral indices performance (Roy et al., 2006; Parks et al., 2014).

The convenience of validations in different scenarios is characteristic of empirical models (De Santis and Chuvieco, 2007). Future research to avoid this time-consuming process may be focused on the development of accurate models supported on more generalizable physically-based methods such as RTM or SMA.

\section{Conclusions}

The results found in our study constitute a novelty in the field of burn severity initial assessment using remote sensing imagery. This is the first evaluation of the performance of different spectral indices (reflective, thermal and mixed) as suitable tools to match field burn severity (site, vegetation and soil burn severities) throughout climatic regions in the Mediterranean Basin. Moreover, we proposed and evaluated a new spectral index, the dNBR-EVI, for increasing the transferability along climatic regions (Mediterranean, Transition and Oceanic).

Specifically, our results demonstrated that reflective indices based on dNBR fitted field values of burn severity better than thermal metrics and mixed ones (combining thermal and optical information).

Besides, in fire-prone pine forests in the Mediterranean Basin, remotely sensed indices indicated better site and vegetation burn severity than soil burn severity.

Most spectral indices used, such as dNBR, showed variable behaviour along the climatic gradient to match burn severity. In order to solve this problem, we proposed an alternative index for initial burn severity assessments using Landsat reflective bands: the dNBR-EVI. We concluded that this index performs better than the other studied indices, showing the best fit to burn severity field data and the best transferability throughout the climatic gradient (Mediterranean-Transition-Oceanic).

Finally, we recommended further evaluations of the performance and suitability of the new dNBR-EVI index for extended assessments of burn severity, as well as in other types of ecosystems, and different geographical regions or climatic situations. Likewise, we highlight the necessity to enhance the current capacity of remotely sensed methods to detect soil burn severity, a crucial factor in areas with high post-fire erosion vulnerability, such as fire prone ecosystems in the Mediterranean Basin.

\section{Uncited reference}

Parsons et al., 2010

\section{Acknowledgements}

This research was financially supported by the Spanish Ministry of Economy and Competitiveness, and the European Regional Development Fund (ERDF), in the framework of the GESFIRE project (AGL2013-48189-C2-1-R); and by the Regional Government of Castilla y León in the framework of the FIRECYL project (LE033U14). We are grateful for technical help provided by Rut Díez Romero, supported by the European Social Fund and Youth Employment Initiative through 
the Regional Government of Castilla y León (workplace ULE-15). Víctor Fernández-García was supported by a predoctoral fellowship from the Spanish Ministry of Education (FPU14/00636).

We would like to thank the emergency service and forest firefighters of Asturias and Extremadura for showing us the study areas and for their help getting to the field plots. We are also grateful to Hugh D. Safford (University of California-Davis) and collaborators for helping us to understand better the use of remote sensing methods for burn severity assessments.

\section{References}

AEMET-IM, 2011. Air temperature and precipitation (1971-2000). In: Iberian Climate Atlas. Agencia Estatal de Meteorología, Ministerio de Medio Ambiente y Medio Rural y Marino. Instituto de Meteorologia de Portugal.

Alcañiz, M., Outeiro, L., Francos, M., Farguell, J., Úbeda, X., 2016. Long-term dynamics of soil chemical properties after a prescribed fire in a Mediterranean forest (Montgrí Massif, Catalonia, Spain). Sci. Total Environ. 572, 1329-1335. https://doi.org/10.1016/j. scitotenv.2016.01.115.

Anderson, H.E., 1982. Aids to determining fuel models for estimating fire behavior. In: USDA Forest Service, General Technical Report, INT-122.

Barsi, J.A., Schott, J.R., Palluconi, F.D., Hook, S.J., 2005. Validation of a web-based atmospheric correction tool for single thermal band instruments. Earth observing systems X. Proc. SPIE 5882. https://doi.org/10.1117/12.619990.

Box, E.O., 1981. Macroclimate and Plant Forms. An Introduction to Predictive Modeling in Phytogeography. Dr. W. Junk Publishers, The Hague, https://doi.org/10.1007/ 978-94-009-8680-0.

Calvo, L., Santalla, A., Valbuena, L., Marcos, E., Tárrega, R., Luis-Calabuig, E., 2008. Post-fire natural regeneration of a Pinus pinaster forest in NW Spain. Plant Ecol. 197, 81-90. https://doi.org/10.1007/s11258-007-9362-1.

Calvo, L., Hernández, V., Valbuena, L., Taboada, A., 2016. Provenance and seed mass determine seed tolerance to high temperatures associated to forest fires in Pinus pinaster. Ann. For. Sci. 73, 381-391. https://doi.org/10.1007/s13595-015-0527-0.

Cansler, C.A., McKenzie, D., 2012. How robust are burn severity indices when applied in a new region? Evaluation of alternate field-based and remote-sensing methods. Remote Sens. 4, 456-483. https://doi.org/10.3390/rs4020456.

Catry, F.X., Pausas, J.G., Moreira, F., Fernandes, P.M., Rego, F., 2013. Post-fire response variability in Mediterranean Basin tree species in Portugal. Int. J. Wildland Fire 22, 919-932. https://doi.org/10.1071/WF12215.

Certini, G., 2005. Effects of fire on properties of forest soils: a review. Oecologia 143, 1-10. https://doi.org/10.1007/s00442-004-1788-8.

Céspedes, B., Luna, B., Pérez, B., Urbieta, I.R., Moreno, J., 2014. Burning season effects on the short-term post-fire vegetation dynamics of a Mediterranean heathland. Appl. Veg. Sci. 17, 86-96. https://doi.org/10.1111/avsc.12053.

Chen, X., Vogelmann, J.E., Rollins, M., Ohlen, D., Key, C.H., Yang, L., Huang, C., Shi, H., 2011. Detecting post-fire burn severity and vegetation recovery using multitemporal remote sensing spectral indices and field-collected composite burn index data in a ponderosa pine forest. Int. J. Remote Sens. 32, 7905-7927.

Chu, T., Guo, X., 2014. Remote sensing techniques in monitoring post-fire effects and patterns of forest recovery in boreal forest regions: a review. Remote Sens. 6, 470-520. https://doi.org/10.3390/rs6010470.

Chuvieco, E., 2010. Teledetección ambiental. La observación de la Tierra desde el espacio, 3rd ed. Ariel, Barcelona.

Chuvieco, E., Riaño, D., Danson, F.M., Martin, P., 2006. Use of a radiative transfer model to simulate the postfire spectral response to burn severity. J. Geophys. Res. 111 G04S09https://doi.org/10.1029/2005JG000143.

Day, N.J., Carriere, S., Baltzer, J.L., 2017. Annual dynamics and resilience in post-fire boreal understory vascular plant communities. For. Ecol. Manag. 401, 264-272. https:// doi.org/10.1016/j.foreco.2017.06.062

De Santis, A., Chuvieco, E., 2007. Burn severity estimation from remotely sensed data: performance of simulation versus empirical models. Remote Sens. Environ. 108, 422-435. https://doi.org/10.1016/j.rse.2006.11.022.

De Santis, A., Chuvieco, E., 2009. GeoCBI: a modified versión of the Composite Burn Index for the initial assessment of the short-term burn severity from remotely sensed data. Remote Sens. Environ. 113, 554-562. https://doi.org/10.1016/j.rse.2008.10.011.

De Santis, A., Chuvieco, E., Vaughan, P.J., 2009. Short-term assessment of burn severity using the inversion of PROSPECT and GeoSail models. Remote Sens. Environ. 113, 126-136. https://doi.org/10.1016/j.rse.2008.08.008.

De Santis, A., Asner, G.P., Vaughan, P.J., Knapp, D.E., 2010. Mapping burn severity and burning efficiency in California using simulation models and Landsat imagery. Remote Sens. Environ. 114, 1535-1545. https://doi.org/10.1016/j.rse.2010.02.008.

Dimitrakopoulos, A.P., Mitsopoulos, I.D., Kaliva, A., 2011. Short communication. Comparing flammability traits among fire-stricken (low elevation) and non fire-stricken (high elevation) conifer forest species of Europe: a test of the Mutch hypothesis. For. Syst. 22, 134-137. https://doi.org/10.5424/fs/2013221-02475.

Doblas-Miranda, E., Alonso, R., Arnan, X., Bermejo, V., Brotons, L., de las Heras, J., Estiarte, M., Hódar, J.A., Llorens, P., Lloret, F., López-Serrano, F.R., Martínez-Vilalta, J., Moya, D., Peñuelas, J., Pino, J., Rodrigo, A., Roura-Pascual, N., Valladares, F., Vilà,
M., Zamora, R., Retana, J., 2017. A review of the combination among global change factors in forests, shrublands and pastures of the Mediterranean Region: beyond drought effects. Glob. Planet. Chang. 148, 42-54. https://doi.org/10.1016/j.gloplacha.2016. 11.012 .

Epting, J., Verbyla, D.L., Sorbel, B., 2005. Evaluation of remotely sensed indices for assessing burn severity in interior Alaska using Landsat TM and ETM +. Remote Sens. Environ. 96, 328-339. https://doi.org/10.1016/j.rse.2005.03.002.

Fernández, C., Vega, J.A., 2016. Evaluation of RUSLE and PESERA models for predicting soil erosion losses in the first year after wildfire in NW Spain. Geoderma 273, 64-72. https://doi.org/10.1016/j.geoderma.2016.03.016.

Fernández-Manso, A., Quintano, C., 2015. Evaluating Landsat ETM + emissivity-enhanced spectral indices for burn severity discrimination in Mediterranean forest ecosystems. Remote Sens. Lett. 6, 302-310. https://doi.org/10.1080/2150704X.2015.1029093.

Fernández-Manso, O., Quintano, C., Fernández-Manso, A., 2009. Combining spectral mixture analysis and object-based classification for fire severity mapping. For. Syst. 18 296-313. https://doi.org/10.5424/fs/2009183-01070.

Fernández-Manso, A., Fernández-Manso, O., Quintano, C., 2016. SENTINEL-2A red-edge spectral indices suitability for discriminating burn severity. Int. J. Appl. Earth Obs. Geoinf. 50, 170-175. https://doi.org/10.1016/j.jag.2016.03.005.

Gao, X., Huete, A.R., Ni, W., Miura, T., 2000. Optical-biophysical relationships of vegetation spectra without background contamination. Remote Sens. Environ. 74, 609-620. https://doi.org/10.1016/S0034-4257(00)00150-4.

García-Llamas, P., Calvo, L., Álvarez-Martínez, J.M., Suárez-Seoane, S., 2016. Using remote sensing products to classify landscape. A multi-spatial resolution approach. Int. J. Appl. Earth Obs. Geoinf. 50, 95-105. https://doi.org/10.1016/j.jag.2016.03.010.

González-de-Vega, S., De las Heras, J., Moya, D., 2016. Resilience of Mediterranean terrestrial ecosystems and fire severity in semiarid areas: responses of Aleppo pine forests in the short, mid and long term. Sci. Total Environ. 573, 1171-1177. https://doi.org/ 10.1016/j.scitotenv.2016.03.115.

Hantson, S., Chuvieco, E., 2011. Evaluation of different topographic correction methods for Landsat imagery. Int. J. Appl. Earth Obs. Geoinf. 13, 691-700. https://doi.org/10. 1016/j.jag.2011.05.001.

Harris, S., Veraverbeke, S., Hook, S., 2011. Evaluating spectral indices for assessing fire severity in Chaparral ecosystems (Southern California) using MODIS/ASTER (MAS TER) airborne simulator data. Remote Sens. 3, 2403-2419.

Holden, Z.A., Morgan, P., Smith, A.M.S., Vierling, L., 2010. Beyond Landsat: a comparison of four satellite sensors for detecting burn severity in ponderosa pine forests of the Gila Wilderness, NM, USA. Int. J. Wildland Fire 19, 449-458. https://doi.org/10. 1071/WF07106.

Holden, S.R., Rogers, B.M., Treseder, K.K., Randerson, J., 2016. Fire severity influences the response of soil microbes to a boreal forest fire. Environ. Res. Lett. 11, 035004https: //doi.org/10.1088/1748-9326/11/3/035004.

Hothorn, T., Bretz, F., Westfall, P., Heiberger, R.M., Schuetzenmeister, A., Scheibe, S., 2017. multcomp: Simultaneous Inference in General Parametric Models. R package version 1. 4-7 https://cran.r-project.org//package = multcomp.

Hudak, A.T., Morgan, P., Bobbitt, M.J., Smith, A.M.S., Lewis, S.A., Lentile, L.B., Robichaud, P.R., Clark, J.T., McKinley, R.A., 2007. The relationship of multispectral satellite imagery to immediate fire effects. In: Fire Ecology Special Issue. 3, pp. 64-90.

Huete, A., Didan, K., Miura, T., Rodriguez, E., Gao, X., Ferreira, L., 2002. Overview of the radiometric and biophysical performance of the MODIS vegetation indices. Remote Sens. Environ. 83, 195-213. https://doi.org/10.1016/S0034-4257(02)00096-2.

Johnstone, J.F., Hollinsworth, T.N., Chapin, F.S., Mack, M., 2010. Changes in fire regime break the legacy lock on successional trajectories in Alaskan boreal forest. Glob. Chang. Biol. 16, 1281-1295. https://doi.org/10.1111/j.1365-2486.2009.02051.x.

Kasischke, E.S., Turetsky, M.R., Ottmar, R.D., French, N.H.F., Hoy, E.E., Kane, E.S., 2008 Evaluation of the composite burn index for assessing fire severity in Alaskan black spruce forests. Int. J. Wildland Fire 17, 515-526. https://doi.org/10.1071/WF08002.

Keeley, J.E., 2009. Fire intensity, fire severity and burn severity: a brief review and suggested usage. Int. J. Wildland Fire 18, 116-126. https://doi.org/10.1071/WF07049.

Key, C.H., 2006. Ecological and sampling constraints on defining landscape fire severity. Fire Ecol. 2, 34-59. https://doi.org/10.4996/fireecology.0202034.

Key, C.H., Benson, N.C., 1999. Measuring and remote sensing of burn severity: the CBI and NBR. In: Neuenschwander, L.F., Ryan, K.C. (Eds.), Proceedings Joint Fire Science Conference and Workshop. Vol. II. University of Idaho and International Association of Wildland Fire, Boise, ID, pp. 15-17.

Key, C.H., Benson, N.C., 2006. Landscape assessment (LA) sampling and analysis methods. In: USDA Forest Service General Technical Report, RMRS-GTR-164-CD.

Kong, J.J., Yang, J., Chu, H., Xiang, X., 2015. Effects of wildfire and topography on soil nitrogen availability in a boreal larch forest of northeastern China. Int. J. Wildland Fire 24, 433-442. https://doi.org/10.1071/WF13218.

2017. Landsat 7 Science Data Users Handbook. In: https://landsat.gsfc.nasa.gov/ landsat-7-science-data-users-handbook/, Accessed 1 June 2017.

2016. Landsat 8 (L8) Data Users Handbook. In: http://landsat.usgs.gov/18handbook.php, Accessed 1 December 2016.

Lehmann, J.R.K., Große-Stoltenberg, A., Römer, M., Oldeland, J., 2015. Field spectroscopy in the VNIR-SWIR region to discriminate between Mediterranean native plants and exotic-invasive shrubs based on leaf tannin content. Remote Sens. 7, 1225-1241. https: //doi.org/10.3390/rs70201225.

Lentile, L.B., Smith, A.M.S., Hudak, A.T., Morgan, P., Bobbitt, M.J., Lewis, S.A., Robichaud, P.R., 2009. Remote sensing for prediction of 1-year post-fire ecosystem condition. Int. J. Wildland Fire 18, 594-608. https://doi.org/10.1071/WF07091. 
Lin, C., Wu, C., Tsogt, K., Ouyang, Y., Chang, C., 2015. Effects of atmospheric correction and pansharpening on LULC classification accuracy using WorldView-2 imagery. Inf. Process. Agric. 2, 25-36. https://doi.org/10.1016/j.inpa.2015.01.003.

Lindner, M., Garcia-Gonzalo, J., Kolström, M., Geen, T., Reguera, R., Maroschek, M., Seidl, R., Lexer, M.J., Netherer, S., Schopf, A., Kremer, A., Delzon, S., Barbati, A., Marchetti, M., Corona, P., 2008. Impacts of climate change on European forests and options for adaptation. In: Report to the European Commission Directorate-General for Agriculture and Rural Development. AGRI-2007-G4-06.

Liu, Z., 2016. Effects of climate and fire on short term vegetation recovery in the boreal larch forests of Northeastern China. Sci. Rep. 6, 37572. https://doi.org/10.1038/ srep37572.

López-García, M.J., Caselles, V., 1991. Mapping burns and natural reforestation using thematic mapper data. Geocarto Int. 1, 31-37. https://doi.org/10.1080/ 10106049109354290.

Madani, N., Kimball, J.S., Jones, L.A., Parazoo, N.C., Guan, K., 2017. Global analysis of bioclimatic controls on ecosystem productivity using satellite observations of solar-induced chlorophyll fluorescence. Remote Sens. 9, 530, http://dx.doi.org/3390/ rs9060530.

MAGRAMA, 2009. Mapa de frecuencia de incendios forestales por término municipal. Web Map Service. In: http://wms.magrama.es/sig/Biodiversidad/Incendios/wms.aspx, Accessed 21 June 2017.

Mänd, P., Hallik, L., Peñuelas, J., Nilson, T., Duce, P., Emmett, B.A., Beier, C., Estiarte, M., Garadnai, J., Kalapos, T., Schmidt, I.K., Kovács-Láng, E., Prieto, P., Tietema, A., Westerveld, J.W., Kull, O., 2010. Responses of the reflectance indices PRI and NDVI to experimental warming and drought in European shrublands along a north-south climatic gradient. Remote Sens. Environ. 114, 626-636. https://doi.org/10.1016/j.rse. 2009.11.003.

Marcos, E., Villalón, C., Calvo, L., Luis-Calabuig, E., 2009. Short-term effects of experimental burning on soil nutrients in the Cantabrian heathlands. Ecol. Eng. 35, 820-828. https://doi.org/10.1016/j.ecoleng.2008.12.011.

Meddens, A.J.H., Kolden, C.A., Lutz, J.A., 2016. Detecting unburned areas within wildfire perimeters using Landsat and ancillary data across the northwestern United States. Remote Sens. Environ. 186, 275-285. https://doi.org/10.1016/j.rse.2016.08.023.

Meng, R., Wu, J., Schwager, K.L., Zhao, F., Dennison, P.E., Cook, B.D., Brewster, K., Green, T.M., Serbin, S.P., 2017. Using high spatial resolution satellite imagery to map forest burn severity across spatial scales in a Pine Barrens ecosystem. Remote Sens. Environ. 191, 95-109. https://doi.org/10.1016/j.rse.2017.01.016.

Miller, J.D., Thode, A.E., 2007. Quantifying burn severity in a heterogeneous landscape with a relative version of the delta normalized burn ratio (dNBR). Remote Sens. Environ. 109, 66-80. https://doi.org/10.1016/j.rse.2006.12.006.

Miller, J.D., Safford, H.D., Crimmins, M., Thode, A.E., 2009. Quantitative evidence for increasing forest fire severity in the Sierra Nevada and Southern Cascade Mountains, California and Nevada, USA. Ecosystems 12, 16-32. https://doi.org/10.1007/ s10021-008-9201-9.

Moreira, F., Viedma, O., Arianoutsou, M., Curt, T., Koutsias, N., Rigolot, E., Barbati, A., Corona, P., Vaz, P., Xanthopoulos, G., Mouillot, L., Bilgiri, E., 2011. Landscape - wildfire interactions in Southern Europe: implications for landscape management. J. Environ. Manag. 92, 2389-2402. https://doi.org/10.1016/j.jenvman.2011.06.028.

Myneni, R.B., Hoffman, S., Knyazikhin, Y., Privette, J.L., Glassy, J., Tian, Y., Wang, Y., Song, X., Zhang, Y., Smith, G.R., Lotsch, A., Friedl, M., Morisette, J.T., Votava, P., Nemani, R.R., Running, S.W., 2002. Global products of vegetation leaf area and fraction absorbed PAR from year one of MODIS data. Remote Sens. Environ. 83, 214-231. https://doi.org/10.1016/S0034-4257(02)00074-3.

Nunes, A.N., Lourenço, L., Castro Meira, A.C., 2016. Exploring spatial patterns and drivers of forest fires in Portugal (1980-2014). Sci. Total Environ. 573, 1190-1202. https:// doi.org/10.1016/j.scitotenv.2016.03.121.

Parks, S.A., Dillon, G.K., Miller, C., 2014. A new metric for quantifying burn severity: the relativized burn ratio. Remote Sens. 6, 1827-1844. https://doi.org/10.3390/ rs6031827.

Parks, S.A., Miller, C., Abatzoglou, J.T., Holsinger, L.M., Parisien, M.A., Dobrowski, S.Z., 2016. How will climate change affect wildland fire severity in the western US?. Environ. Res. Lett. 11, 035002https://doi.org/10.1088/1748-9326/11/3/035002.

Pausas, J.G., Keeley, J.E., 2014. Evolutionary ecology of resprouting and seeding in fire-prone ecosystems. New Phytol. 204, 55-65. https://doi.org/10.1111/nph.12921.

Pausas, J.G., Llovet, J., Rodrigo, A., Vallejo, R., 2008. Are wildfires a disaster in the Mediterranean basin?-a review. Int. J. Wildland Fire 17, 713-723. https://doi.org/10. 1071/WF07151.

Perkins, T., Adler-Golden, S., Matthew, M.W., Berk, A., Bernstein, L.S., Lee, J., Fox, M., 2012. Speed and accuracy improvements in FLAASH atmospheric correction of hyperspectral imagery. Opt. Eng. 51, 111707https://doi.org/10.1117/1.OE.51.11.111707.

Picotte, J.J., Robertson, K.M., 2011. Validation of remote sensing of burn severity in south-eastern US ecosystems. Int. J. Wildland Fire 20, 453-464. https://doi.org/10. 1071/WF10013.

Pinheiro, J., Bates, D., DebRoy, S., Sarkar, D., R Core Team, 2017. nlme: Linear and Nonlinear Mixed Effects Models. R package version 3. 1-131 https://cran.r-project.org/ package $=$ nlme

Quintano, C., Fernández-Manso, A., Calvo, L., Marcos, E., Valbuena, L., 2015. Land surface temperature as potential indicator of burn severity in forest Mediterranean ecosystems. Int. J. Appl. Earth Obs. Geoinf. 36, 1-12. https://doi.org/10.1016/j.jag.2014. 10.015 .
Quintano, C., Fernández-Manso, A., Roberts, D.A., 2017. Burn severity mapping from Landsat MESMA fraction images and land surface temperature. Remote Sens. Environ. 190, 83-95. https://doi.org/10.1016/j.rse.2016.12.009.

R Core Team, 2016. R: A language and environment for statistical computing. R Foundation for Statistical Computing, Vienna, Austria, URL http://www.R-project.org/.

Reichle, R.H., Koster, R.D., 2004. Bias reduction in short records of satellite soil moisture Geophys. Res. Lett. 31, L19501https://doi.org/10.1029/2004GL020938.

Robichaud, P., Lewis, S., Laes, D., Hudak, A., Kokaly, R., Zamudio, J., 2007. Post-fire soil burn severity mapping with hyperspectral image unmixing. Remote Sens. Environ. 108, 467-480. https://doi.org/10.1016/j.rse.2006.11.027.

Rodríguez-Alleres, M., Varela, M.E., Benito, E., 2012. Natural severity of water repellency in pine forest soils from NW Spain and influence of wildfire severity on its persistence. Geoderma 191, 125-131. https://doi.org/10.1016/j.geoderma.2012.02.006.

Rother, M.T., Veblen, T.T., 2017. Climate drives episodic conifer establishment after fire in dry ponderosa pine forests of the Colorado Front Range, USA. Forests 8, 159. https: //doi.org/10.3390/f8050159.

Rouse, J.W., Haas, R.H., Schell, J.A., Deering, D.W., 1973. Monitoring vegetation systems in the great plains with ERTS. In: Proceedings of the Third ERTS Symposium. NASA SP-351, 1. NASA, Washington DC, U.S., pp. 309-317.

Roy, D.P., Boschetti, L., Trigg, S.N., 2006. Remote sensing of fire severity: assessing the performance of the Normalized Burn Ratio. IEEE Geosci. Remote Sens. Lett. 3, 112-116. https://doi.org/10.1109/LGRS.2005.858485.

Roy, D.P., Kovalskyy, V., Zhang, H.K., Vermote, E.F., Yan, L., Kumar, S.S., Egorov, A., 2016. Characterization of Landsat-7 to Landsat-8 reflective wavelength and normalized difference vegetation index continuity. Remote Sens. Environ. 185, 57-70. https: //doi.org/10.1016/j.rse.2015.12.024.

San-Miguel-Ayanz, J., Durrant, T., Boca, R., Libertà, G., Bocacci, F., Di Leo, M., López-Pérez, J., Schulte, E., 2016. Forest fires in Europe, Middle East and North Africa 2015. In: Joint Research Center of the European Commission Technical Reports, EUR 28158EN. https://doi.org/10.2788/914.

Schwilk, D.W., Caprio, A.C., 2011. Scaling from leaf traits to fire behaviour: community composition predicts fire severity in a temperate forest. J. Ecol. 99, 970-980. https:// doi.org/10.1111/j.1365-2745.2011.01828.x

Sikkink, P.G., 2015. Comparison of six fire severity classification methods using Montana and Washington wildland fires. In: Keane, R.E., Jolly, M., Parsons, R., Riley, K. (Eds.), Proceedings of the Large Wildland Fires Conference; Proc.RMRS-P-73. United States Department of Agriculture, Missoula, MT, pp. 213-226.

Soverel, N.O., Coops, N.C., Perrakis, D.B., Daniels, L., Gergel, S., 2011. The transferability of a dNBR-derived model to predict burn severity across ten wildland fires in Western Canada. Int. J. Wildland Fire 20, 1-14. https://doi.org/10.1071/WF10081.

Steel, Z.L., Safford, H.D., Viers, J.H., 2015. The fire frequency-severity relationship and the legacy of fire suppression in California forests. Ecosphere 6 (8)https://doi.org/10. 1890/ES14-00224.1.

Tanase, M., de la Riva, J., Pérez-Cabello, F., 2011. Estimating burn severity at the regional level using optically based indices. Can. J. For. Res. 41, 863-872. https://doi.org/10. 1139/X11-011.

Teillet, P.M., Guindon, B., Goodenough, D.G., 1982. On the slope-aspect correction of multispectral scanner data. Can. J. Remote. Sens. 8, 84-106.

Van der Knijff, J.M., Jones, R.J.A., Montanarella, L., 2000. Soil erosion risk assessment in Europe. In: Joint Research Center of the European Commission Report, EUR19044EN.

Varela, M.E., Benito, E., Keizer, J.J., 2015. Influence of wildfire severity on soil physical degradation in two pine forest stands of NW Spain. Catena 133, 342-348. https://doi org $/ 10.1016 /$ j.catena.2015.06.004.

Vega, J.A., Fontúrbel, T., Merino, A., Fernández, C., Ferreiro, A., Jiménez, E., 2013. Testing the ability of visual indicators of soil burn severity to reflect changes in soil chemical and microbial properties in pine forests and shrubland. Plant Soil 369, 73-91. https: //doi.org/10.1007/s11104-012-1532-9.

Veraverbeke, S., Verstraeten, W., Lhermitte, S., Goossens, R., 2010. Evaluating Landsa Thematic Mapper spectral indices for estimating burn severity of the 2007 Peloponnese wildfires in Greece. Int. J. Wildland Fire 19, 558-569. https://doi.org/10.1071/ WF09069.

Veraverbeke, S., Harris, S., Hook, S., 2011. Evaluating spectral indices for burned area discrimination using MODIS/ASTER (MASTER) airborne simulator data. Remote Sens. Environ. 115, 2702-2709. https://doi.org/10.1016/j.rse.2011.06.010.

Veraverbeke, S., Hook, S., Hulley, G., 2012. An alternative spectral index for rapid fire severity assessments. Remote Sens. Environ. 123, 72-80. https://doi.org/10.1016/j. rse.2012.02.025.

Vlassova, L., Pérez-Cabello, F., 2016. Effects of post-fire wood management strategies on vegetation recovery and land surface temperature (LST) estimated from Landsat images. Int. J. Appl. Earth Obs. Geoinf. 44, 171-183. https://doi.org/10.1016/j.jag. 2015.08.011.

Vlassova, L., Pérez-Cabello, F., Mimbrero, M., Llovería, R., García-Martín, A., 2014. Analysis of the relationship between land surface temperature and wildfire severity in a series of Landsat images. Remote Sens. 6, 6136-6162. https://doi.org/10.3390/ rs6076136.

Wu, Z., He, H.S., Liang, Y., Cai, L., Lewis, B.J., 2013. Determining relative contributions of vegetation and topography to burn severity from LANDSAT imagery. Environ. Manag. 52, 821-836. https://doi.org/10.1007/s00267-013-0128-3.

Wu, Z., Middleton, B., Hetzler, R., Vogel, J., Dye, D., 2015. Vegetation burn severity mapping using Landsat-8 and WorldView-2. Photogramm. Eng. Remote. Sens. 81, 143-154. https://doi.org/10.14358/PERS.81.2.143. 
Xiao, J., Moody, A., 2008. Geographical distribution of global greening trends and their climatic correlates: 1982-1998. Int. J. Remote Sens. 26, 2371-2390. https://doi.org/ $10.1080 / 01431160500033682$.

Yu, X., Guo, X., Wu, Z., 2014. Land surface temperature retrieval from Landsat 8 TIRS - comparison between radiative transfer equation-based method, split window algorithm and single channel method. Remote Sens. 6, 9829-9852. https://doi.org/ $10.3390 /$ rs6109829.

Yudina, P.K., Ivanova, L.A., Ronzhina, D.A., Zolotareva, N.V., Ivanov, L.A., 2017. Variation of leaf traits and pigment content in three species of steppe plants depending on the climate aridity. Russ. J. Plant Physiol. 64, 410-422. https://doi.org/10.1134/ S1021443717020145.
Zheng, Z., Zeng, Y., Li, S., Huang, W., 2016. A new burn severity index based on land surface temperature and enhanced vegetation index. Int. J. Appl. Earth Obs. Geoinf. 45 84-94. https://doi.org/10.1016/j.jag.2015.11.002.

Zhu, Z., Key, C., Ohlen, D., Benson, N., 2006. Evaluate sensitivities of burn-severity mapping algorithms for different ecosystems and fire histories in the United States. In: Final Report to the Joint Fire Science Program. JFSP 01-1-4-12.

Zhu, Z., Bi, J., Pan, Y., Ganguly, S., Anav, A., Xu, L., Samanta, A., Piao, S., Nemani, R.R. Myneni, R.B., 2013. Global data sets of vegetation leaf area index (LAI)3g and fraction of photosynthetically active radiation (FPAR) $3 g$ derived from global inventory modeling and mapping studies (GIMMS) normalized difference vegetation index (NDVI3g) for the period 1981 to 2011. Remote Sens. 5, 927-948. https://doi.org/10. $3390 /$ rs5020927. 